\title{
The Fungal Cell Wall: Structure, Biosynthesis, and Function
}

\author{
NEIL A. R. GOW, ${ }^{1}$ JEAN-PAUL LATGE, ${ }^{2}$ and CAROL A. MUNRO ${ }^{1}$ \\ ${ }^{1}$ Aberdeen Fungal Group, Institute of Medical Sciences, University of Aberdeen, \\ Aberdeen AB252ZD, United Kingdom; ${ }^{2}$ Unité des Aspergillus, Institut Pasteur, Paris, France
}

\begin{abstract}
The molecular composition of the cell wall is critical for the biology and ecology of each fungal species. Fungal walls are composed of matrix components that are embedded and linked to scaffolds of fibrous load-bearing polysaccharides. Most of the major cell wall components of fungal pathogens are not represented in humans, other mammals, or plants, and therefore the immune systems of animals and plants have evolved to recognize many of the conserved elements of fungal walls. For similar reasons the enzymes that assemble fungal cell wall components are excellent targets for antifungal chemotherapies and fungicides. However, for fungal pathogens, the cell wall is often disguised since key signature molecules for immune recognition are sometimes masked by immunologically inert molecules. Cell wall damage leads to the activation of sophisticated fail-safe mechanisms that shore up and repair walls to avoid catastrophic breaching of the integrity of the surface. The frontiers of research on fungal cell walls are moving from a descriptive phase defining the underlying genes and component parts of fungal walls to more dynamic analyses of how the various components are assembled, cross-linked, and modified in response to environmental signals. This review therefore discusses recent advances in research investigating the composition, synthesis, and regulation of cell walls and how the cell wall is targeted by immune recognition systems and the design of antifungal diagnostics and therapeutics.
\end{abstract}

\section{INTRODUCTION}

Fungal cell walls are dynamic structures that are essential for cell viability, morphogenesis, and pathogenesis. The wall is much more than the outer layer of the fungus; it is also a dynamic organelle whose composition greatly influences the ecology of the fungus and whose composition is highly regulated in response to environmental conditions and imposed stresses. A measure of the importance of the cell wall can be appreciated by the fact that approximately one-fifth of the yeast genome is devoted to the biosynthesis of the cell wall $(\underline{1}, \underline{2})$. Of these approximately 1,200 Saccharomyces cerevisiae genes $(\underline{2})$, some are concerned with the assembly of the basic components, others provide substrates for wall materials, and many regulate the assembly process and couple this to environmental challenges. They include genes that encode carbohydrate active enzymes (which can be found in the CAZy database [http://www.cazy .org]) (ㅁ) and include multigene families of chitin and glucan synthases as well as remodeling enzymes such as the glycohydrolases (glucanases, chitinases) and transglycosidases. Many of the building blocks of the cell wall are conserved in different fungal species (4), while other components of the wall are species-specific, and there is perhaps no part of the cell that exhibits more phenotypic diversity and plasticity than the cell wall.

Walls are built to be both malleable and mechanically robust. The high total solute concentration inside fungal cells results in the osmotic uptake of water and the pressing of the cell membrane onto the wall. The resulting turgor pressure has been estimated to be between 0.2 and $10 \mathrm{MPa}$-equivalent to 2 to 20 times atmospheric pressure ( $\underline{5})$. The melanized cell walls of the appressoria of some plant pathogens such as Magnaporthe oryzae can withhold an internal turgor of up to $20 \mathrm{MPa}$. These cell walls are the most robust of all

\footnotetext{
Received: 22 November 2016, Accepted: 2 March 2017 Published: 19 May 2017

Editor: Joseph Heitman, Department of Molecular Genetics and Microbiology, Duke University Medical Center, Durham, NC 27710

Citation: Gow NAR, Latge J-P, Munro CA. 2017. The fungal cell wall: structure, biosynthesis, and function. Microbiol Spectrum 5(3): FUNK-0035-2016. doi:10.1128/microbiolspec.FUNK-0035-2016.

Correspondence: Neil A.R. Gow, n.gow@abdn.ac.uk

C 2017 American Society for Microbiology. All rights reserved.
} 
walls found in nature. Turgor pressure generates the force that enables hyphae to exert mechanical force on the substrates they are penetrating $(\underline{5}, \underline{6})$. Hyphal forces of between 0.01 and $0.1 \mu \mathrm{N} / \mu \mathrm{m}(\underline{5})$ can be exerted at the hyphal tips which are sufficient to enable most vegetative hyphae to penetrate a stiff $8 \%$ (wt/vol) agar. Wall-less cells are invariably spherical, so the cell wall of fungi also determines their complex shapes and changes in cell shape underpinning, morphogenesis, and cellular differentiation. Because the cell wall is also the natural interface between the fungus and its environment, it goes a long way to defining the ecology of fungi by influencing their interactions with substrates and other organisms.

For fungal pathogens of humans, the wall induces innate and adaptive immune responses, and the design of the cell wall sometimes incorporates immune decoys and shields (ㅁ). Similarly, for plant pathogenic fungi the cell wall is detected by receptors in the plant cell that induce local and systemic defense responses ( $\underline{8}$ ). The cell wall provides a valuable source of most diagnostic antigens that are used to detect human fungal infections, and it represents a rich source of unique targets for chemotherapeutic treatment of pathogens. Therefore, fungi are in no small measure defined by, and live through, the interface of their cell walls. Recent progress has been considerable, yet some of the most important and elusive questions in fungal cell biology relate to basic aspects of fungal cell wall biosynthesis and function. This review focuses on the biosynthesis and functions of fungal cell walls with an emphasis on model pathogenic species where the most detailed information is often available.

\section{COMPOSITION AND STRUCTURE}

\section{Structural Organization and Cell Wall Layers}

Fundamentally, fungal walls are all engineered in a similar way. The wall structure directly affects wall function and interactions with the environment including immune recognition by plants and animals. Fibrous and gel-like carbohydrate polymers form a tensile and robust core scaffold to which a variety of proteins and other superficial components are added that together make strong, but flexible, and chemically diverse cell walls. Most cell walls are layered, with the innermost layer comprising a relatively conserved structural skeletal layer and the outer layers more heterogeneous and tailored to the physiology of particular fungi. In most fungal species the inner cell wall consists of a core of covalently attached branched $\beta-(1,3)$ glucan with 3 to $4 \%$ interchain and chitin $(\underline{9}, \underline{10}) . \beta-(1,3)$ Glucan and chitin form intrachain hydrogen bonds and can assemble into fibrous microfibrils that form a basket-like scaffold around the cell. This exoskeleton represents the loadbearing, structural component of the wall that resists the substantial internal hydrostatic pressure exerted on the wall by the cytoplasm and membrane. This branched $\beta-(1,3): \beta-(1,6)$ glucan is bound to proteins and/or other polysaccharides, whose composition may vary with the fungal species (Fig. 1). However, yeast cells have bud scars that tend to have fewer outer cell wall layers covering them and therefore have exposed inner wall chitin and $\beta-(1,3)$ glucan $(11)$. The inner walls of many fungal spores and so-called black yeasts contain complex amorphous polymerized phenolic compounds called melanins, which also add protection-particularly from oxidants and some exoenzymes.

The outer layers of fungi vary much more than the inner skeletal layer (Fig. 1). Yeasts such as Candida and Saccharomyces species and the human pathogen Pneumocystis jiroveci have an outer cell wall comprising highly mannosylated glycoproteins that covers the inner wall. In the yeast cells of some polymorphic fungi such as the human pathogen Histoplasma capsulatum, the outer wall has a layer of $\alpha-(1,3)$ glucan that prevents dectin-1-mediated immune recognition of the underlying $\beta-(1,3)$ glucan by immune cells $(\underline{12})$.

$\alpha-(1,3)$ Glucan plays a prominent role in the organization of the cell wall of many human pathogens but is absent from the Candida and Saccharomyces cell walls. In Aspergillus, an $\alpha-(1,3)$ glucan along with some other amorphous polysaccharides is represented in the alkali-soluble cell wall fraction (13). The basidiomycetous yeast Cryptococcus has a cell wall that is enveloped by a gelatinous capsule composed of glucuronoxylomannan (GXM) and galactoxylomannan (Fig. 1) and that is anchored to the main wall via $\alpha-(1,3)$ glucan (14). The GXM ( $\sim 90 \%$ of the mass of the capsule) is composed of $\alpha$-(1,3)-linked mannan with glucuronic acid, xylose, and $\mathrm{O}$-acetyl branches. The galactoxylomannan is composed of an $\alpha-(1,6)$ galactomannan (GM) backbone with GM side chains substituted with variable numbers of xylose residues (Fig. 1). The synthesis of the Cryptococcus neoformans capsule polysaccharides remains incompletely understood, and few transglycosidases involved in this process have been characterized $(15,16)$. Interestingly, it has been shown that capsule polysaccharides are synthesized intracellularly and secreted via exocytosis through the cell wall (17). 

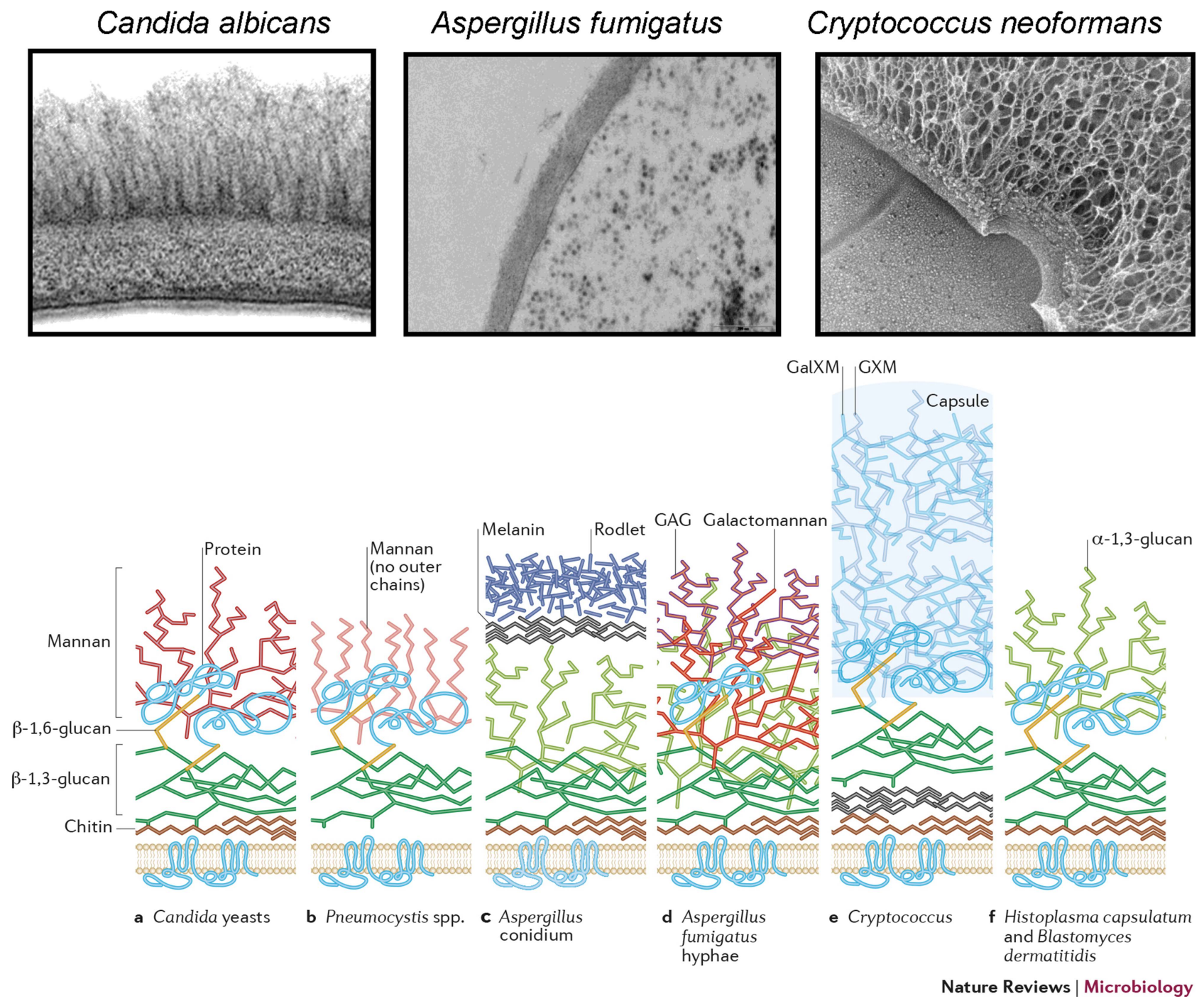

FIGURE 1 Structural organization of the cell walls of fungal pathogens. The upper panels show transmission electron micrograph sections of the cell walls, revealing mannoprotein fibrils in the outer walls of $C$. albicans, the fibril-free cell wall of an $A$. fumigatus hypha, and the elaborate capsule of $C$. neoformans. The cartoons (below) show the major components of the wall and current hypotheses about their interconnections. Most fungi have a common alkali-insoluble core of branched $\beta$ - $(1,3)$ glucan, $\beta$ - $(1,6)$ glucan, and chitin but differ substantially in the components that are attached to this. In C. albicans, the outer wall is heavily enriched with highly mannosylated proteins that are mostly attached via glycosylphosphatidylinositol remnants to $\beta$ - $(1,6)$ glucan and to the $\beta$ - $(1,3)$ glucan-chitin core. In A. fumigatus, typical of many filamentous fungi, mannan chains are of lower molecular weight and are modified with $\beta$ - $(1,5)$ galactofuran. These mannans are not components of glycoproteins but are attached directly to the cell wall core. The cell wall core polysaccharides of $A$. fumigatus are $\beta-(1,3)-\beta-(1,4)$ glucans and are attached to an outer layer of alkali-soluble linear $\alpha-(1,3)(1,4)$ glucan. Conidial walls of Aspergillus have an outer hydrophobin rodlet layer of highly hydrophobic portions (hydrophobins) and a melanin layer; hyphae of Aspergillus have $a-(1,3)$ glucan GM, and galactosaminoglycan (GAG) in the outer cell wall and limited glycosylated proteins. In C. neoformans, an outer capsule is composed of glucuronoxylomannan (GXM) and lesser amounts of galactoxylomannan (GalXM). The capsule is attached to a- $(1,3)$ glucan in the underlying wall, although peptides or other glycans may also be required for anchoring the capsule to the cell wall. The inner wall has a $\beta$ - $(1,3)$ glucan- $\beta$ - $(1,6)$ glucan-chitin core, but most of the chitin is deacetylated to chitosan, and some of the chitosan/chitin may be located further from the membrane. $C$. neoformans also has a layer of melanin whose precise location is not known, but it may be incorporated into several cell wall polysaccharides and may assemble close to the chitin/chitosan layer. Pneumocystis cell walls may lack chitin and the outer chain $N$-mannans but retain core $N$-mannan and $O$-mannan modified proteins (56). Hyphae of $H$. capsulatum and Blastomyces dermatitidis have an outer cell wall layer of $a-(1,3)$ glucan that prevents efficient immune recognition of $\beta-(1,3)$ glucan in the inner cell wall. (From reference $\underline{z}$, with permission.) 
The conidial spores and aerial hyphae of mold are often covered by highly hydrophobic proteins called hydrophobins that form rodlets that protect the spores from enzymes, oxidants, and foraging phagocytes (18). For example, the conidial rodlet protein RodA of Aspergillus fumigatus prevents alveolar macrophages from inducing an immune response, which is delayed until this layer cracks upon spore swelling and germination (Fig. 1) $(19,20)$. However, once the integrity of the rodlet layer of these spores is breached, then the underlying galactosaminoglycan (GAG) and GM and $\beta-(1,3)$ glucan layers can be recognized by alveolar macrophages, enabling the innate immune response to be initiated (21).

The individual components of the cell wall are covalently cross-linked to one another. In A. fumigatus, the branched $\beta-(1,3)(1,6)$ glucan is covalently bound to chitin, a linear $\beta-(1,3)(1,4)$ glucan with a [3Glc $\beta 1-4 \mathrm{Glc} \beta 1$ ] repeating unit and a branched galactomannan composed of a linear $\alpha$-mannan with a repeating mannose oligosaccharide unit [6Man $\alpha 1-2 \mathrm{Man} \alpha 1-2 \mathrm{Man} \alpha 1-2 \mathrm{Man} \alpha$ ] and short chains of $\beta-(1,5)$ galactofuranose residues (22). In Candida albicans, $\beta-(1,3)$ glucan is bound to chitin and $\beta-(1,6)$ glucan, a polymer that is absent from A. fumigatus. In C. albicans, $\beta-(1,6)$ glucan plays an essential role in the structural organization of the cell wall (23) interconnecting $\beta-(1,3)$ glucan and chitin (Fig. 1). In C. neoformans and most other fungi, the covalent linkages between glucans and the other polymers have not been investigated.

In $C$. albicans and $S$. cerevisiae, $\beta-(1,6)$ glucan acts as a linker molecule binding cell wall proteins (CWPs) to the $\beta-(1,3)$ glucan-chitin skeleton via a glycosylphosphatidyl inositol (GPI) remnant (24). In yeast cells of these species, the CWPs represent 30 to $50 \%$ of the dry mass of the wall, of which only 10 to $20 \%$ is polypeptide. A few proteins with internal repeats (Pir) can be attached directly to $\beta$ - $(1,3)$ glucan via an alkali-sensitive $O$-linkage via a mannose side chain (24). In A. fumigatus, the cell wall has a much reduced glycol protein content, and galactosylated mannoproteins are not cell wall-associated and are secreted proteins in transit in the cell wall.

This general arrangement places the structural elements of the cell wall close to the membrane to provide mechanical support, and places the gel-like or hydrophobic polymers to the outside where they can protect the load-bearing elements from degradative enzymes in the environment or act as adhesins to anchor the cell to substrata. A major unresolved issue is how the cell wall polysaccharides and membrane proteins are bound together to guide the cell wall morphogenesis.

\section{Biofilms}

Some of the external gel-like polymers of the outer surface of fungi are extremely well organized, such as in the capsule of C. neoformans, while other fungi, such as some Candida species, form biofilms growing on solid surfaces, where the extracellular matrix has a more loose structure composed of glucans, chitin, nucleic acids, and other polymers $(25,26)$. On top of the C. neoformans capsule there may also be a superficial biofilm that contains GXM as well as polysaccharides that differ from those found in the capsule, with significant amounts of glucose and fucose (27). Biofilms of Pneumocystis carinii and C. albicans are rich in $\beta-(1,3)$ glucans and DNA $(28-$ 30), while Candida tropicalis has a biofilm matrix rich in GlcNAc (31). In C. albicans, growth of the fungus in a biofilm community results in cell wall architectural changes. In A. fumigatus, the extracellular matrix plays an essential role in the organization of the colony by gluing together mycelial threads and is composed of $25 \%$ polysaccharides and $70 \%$ monosaccharides with some hydrophobic proteins and melanin. The extracellular matrix of $A$. fumigatus contains $\alpha-(1,3)$ glucan, GM, and GAG, like the outer cell wall layer (32), and in contrast to other species, lacks $\beta-(1,3)$ glucan and chitin. In human pathogens this biofilm material has been implicated in blocking recognition and immune capture by phagocytic cells.

\section{GENETICS, ENZYMOLOGY, AND BIOSYNTHESIS \\ Biosynthesis of the Polysaccharides}

Polysaccharides such as chitin and glucan are synthesized at the plasma membrane (PM) by transmembrane enzymatic complexes that are targeted to the PM in an inactive form via secretory vesicles and then activated after insertion into the PM (see below). This is in contrast to mannans and other glycoconjugates that are synthesized in the endoplasmic reticulum and Golgi, where they may be conjugated to cell wall proteins, and then brought to the cell wall by the classical secretory route via secretory vesicles. All synthases use nucleotide diphosphate-sugars as substrates, so enzymes of the metabolic pathways responsible for the synthesis of nucleotide sugars are essential for the construction of the cell wall and are rate-limiting.

\section{Core Polysaccharides: Chitin and $\beta-(1,3)$ Glucan}

The major synthases that make chitin and glucans reside in the PM and use UDP-sugars as the substrate for the 
formation of the nascent polysaccharide that is extruded into the cell wall (Fig. 2A). In the cell wall, polysaccharides can then hydrogen-bond together or be crosslinked or branched by enzymes that reside in the cell wall (Fig. 2B,C). The pathway of cell wall synthesis therefore comprises biosynthetic reactions that take place inside the cell in the Golgi, at the PM, and in the cell wall itself.

UDP- $N$-acetylglucosamine is the substrate for chitin synthesis. Chitin is composed of linear chains of $\beta-(1,4)$ $\mathrm{N}$-acetylglucosamine and represents the most ancestral structural polysaccharide in the fungal cell wall. Families of chitin synthases responsible for the synthesis of chitin have been identified bioinformatically, with molecular weights of 100 to $130 \mathrm{kDa}$. The exact biochemical functions of many chitin synthase isoforms remain to be established (33-36), and although some isoforms may have redundant functions, in several species there is evidence that individual chitin synthase enzymes perform distinct and specific functions under normal growth conditions. Although the enzymological product of all chitin synthase enzymes is a homopolymer with only one linkage, individual chitin synthase enzymes can synthesize chitin fibrils of differing architecture, perhaps due to differences in the folding and intrachitin hydrogen bonding of the primary chain (37). Two families of fungal chitin synthases with three classes in the first family (I, II, III) and four classes in the second family (IV, V, VI, VII) have been identified based on amino acid sequence (38). Four classes (III, V, VI, VII) are specific to filamentous fungi $(\underline{36}, 39)$. The significance of each of these seven classes is not well understood, since mutations in members of a common family do not always result in a similar phenotype. However, two groups of mutants can be identified: the first has reduced chitin content but normal chitin synthase activity in vitro, whereas the second is affected in enzyme activity but has regular cell wall chitin content. In addition, other genes, named $\mathrm{CHS}$, are not associated with chitin synthase activity but are involved in the regulation of chitin synthase activity or localization. Some chitin synthases appear to be zymogens that are activated by proteolysis, and there is also evidence that some chitin synthase enzymes are regulated by phosphorylation $(40,41)$. Some fungi have more than $20 \mathrm{CHS}$ genes, and some have only 1 (42). A. fumigatus and C. neoformans are both predicted to have eight CHS genes, and Wangiella dermatitidis has five; all of these CHS genes are nonessential, although the chs $3 \Delta$ mutant of C. neoformans cannot grow at $37^{\circ} \mathrm{C}$. In contrast, C. albicans has a CHS family of four genes, and the class II CHS1 is essential for cell viability (43). In Aspergillus species, some double chitin synthase mutants are lethal, but most single mutants are viable (39).

The class V and class VII chitin synthase enzymes of filamentous fungi have unconventional myosin-motorlike domains (MMD) (44). These enzymes are often essential for growth, morphogenesis, and virulence, as well as stress tolerance. It is likely that the MMD functions in actin-mediated cytoplasmic transport, and there is evidence for this domain's ability to bind actin and to influence apical localization (45). However, this domain is not required for cellular motility in Aspergillus nidulans and Ustilago maydis, and (느) instead the MMD may function in tethering vesicles in the apical dome, increasing the residence time at that location, and thereby favoring vesicle fusion with the PM (47).

$\beta-(1,3)$ Glucan, the other major cell wall polysaccharide, is synthesized by a PM-bound glucan synthase complex which uses UDP-glucose as a substrate and extrudes linear $\beta-(1,3)$ glucan chains through the membrane into the cell wall, where it can act as a substrate for various transglycosidase enzymes (see below) (48). The protein complex contains at least two proteins: (i) the putative catalytic subunit encoded by the gene(s) FKS/ GSC and (ii) a regulatory subunit encoded by RHO1 with an $\mathrm{M}_{\mathrm{r}}$ of $\sim 20 \mathrm{kDa}$. The Fks/Gsc subunits are the target of the echinocandin family of antifungal drugs and the recently described plant metabolite poacic acid $(\underline{49}, 50)$. Fks subunits have an $\mathrm{M}_{\mathrm{r}}$ of $>200 \mathrm{kDa}$ with up to 16 transmembrane helices and a central hydrophilic domain of about 580 amino acids, which displays a remarkable degree of identity $(>80 \%)$ with all known Fks proteins (48). Two external loops of Fks contain socalled hot-spot regions: sites in which common mutations confer reduced sensitivity to echinocandins (51). Rho1GTPase is regulated by switching between a GDP-bound inactive state to a GTP-bound active state with accompanying conformational changes $(\underline{1})$. There are fewer glucan synthase genes than chitin synthase genes in pathogenic fungi. In A. fumigatus and C. neoformans, FKS1 is unique and essential (52). In C. albicans, three FKS orthologues have been identified, but only one of them, orf19.2929, is associated with echinocandin resistance ( $\underline{53}$ ).

Recently, it was shown in U. maydis that the class VII chitin synthase Mcs1 and the class V chitin synthase 6 (Chs6) can be cotransported on the same secretory vesicle along with the $\beta-(1,3)$ glucan synthase Gsc1 (Fig. 3 ) $(45)$. Moreover, the cocomplex of glucan and chitin synthases seems to be retained at a localized spot of exocytosis and wall synthesis by the tethering effect of the synthases to their nascent polysaccharides that reside within the fabric of the external cell wall (45). 


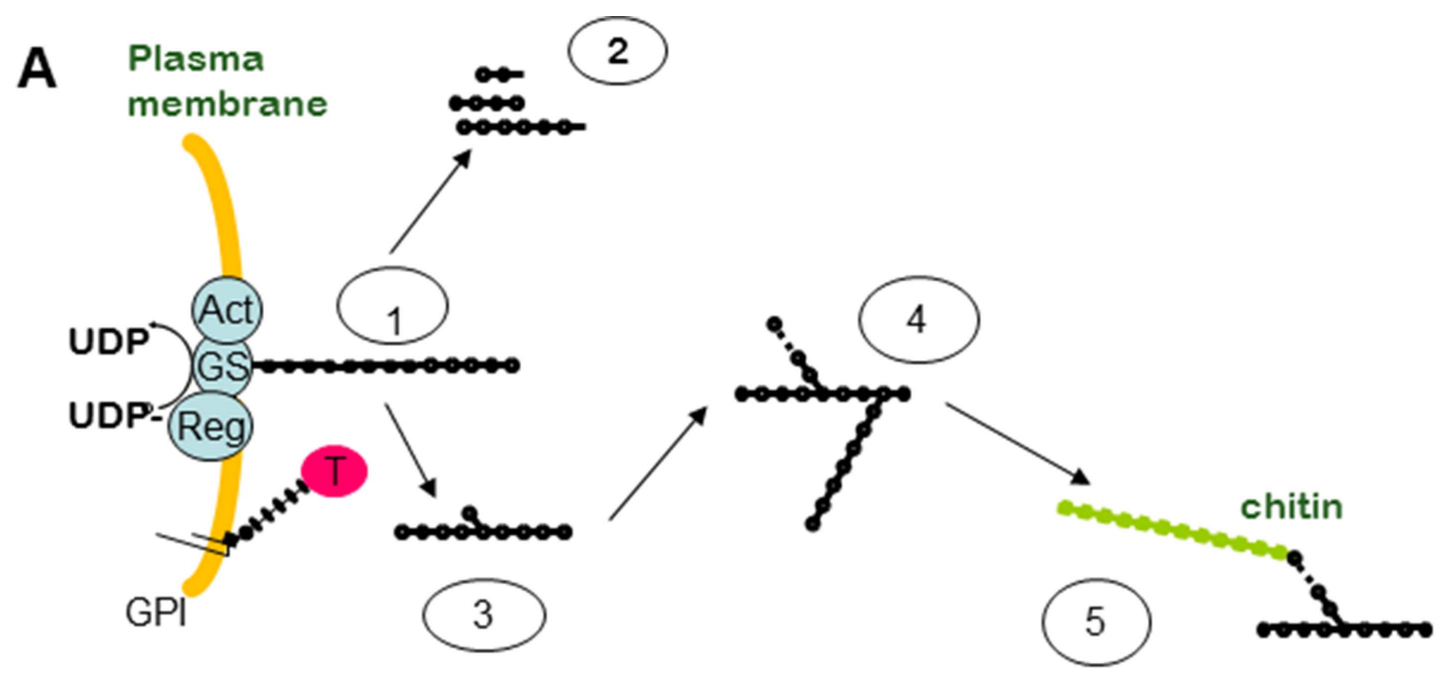

B

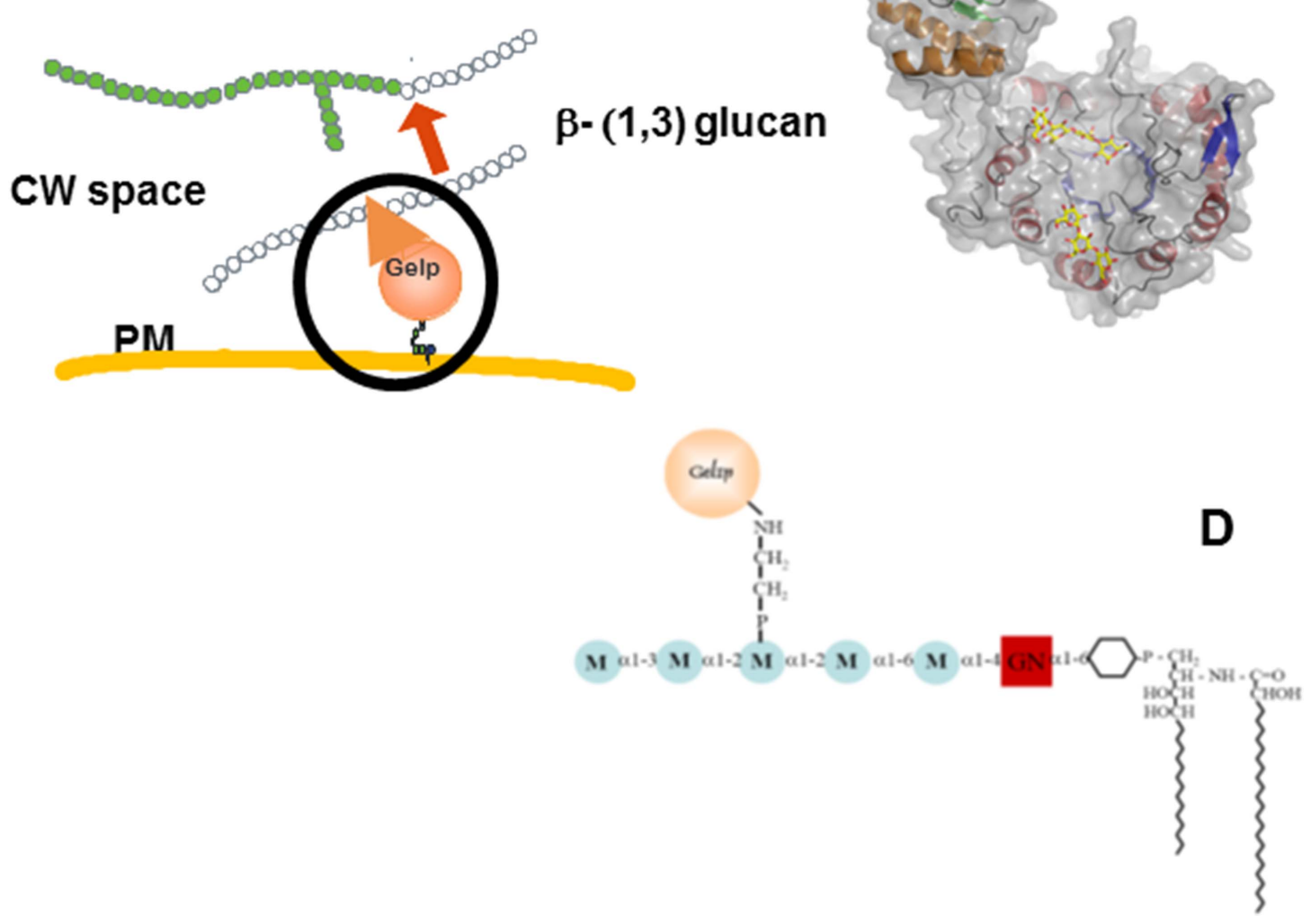

FIGURE 2 Synthesis and remodeling of $\beta$-(1,3) glucan. (A) Putative sequential or concomitant events in the synthesis and remodeling of $\beta-(1,3)$ glucan. 1. Synthesis of linear glucan chains (glucan synthase complex composed of a catalytic [GS], activating [Act], and regulating [Reg] subunits). 2. Hydrolysis of glucans. 3. Branching of $\beta-(1,3)$ glucan. 4 . Elongation of $\beta-(1,3)$ glucan side chains. 5. Cross-linking with branched $[\beta-(1,3)]$ glucan. GPI-anchored transglycosidase or hydrolases (T) bound to the membrane can act on the polysaccharides in the cell wall space. Panel A provides example. (B) An example of GPI-anchored Gel1 protein involved in the elongation of $\beta-(1,3)$ glucan inside the cell wall space. (C) Crystal structure of the S. cerevisiae Gel1 orthologue, Gas2 complex with acceptor and donor oligosaccharides. The enzyme is shown as a ribbon, the glucan binding domain with green strands and orange helices, and the catalytic domain with blue strands and red helices. A gray transparent molecular surface is shown, revealing an elongated groove on the catalytic domain, in which the laminarioligosaccharides (shown as sticks, with yellow carbon atoms) bind. (D) Biochemical organization of a GPI-anchored protein in A. fumigatus. The three domains of the GPI anchor are (i) a phosphoethanolamine linker covalently bound to the protein, (ii) a mannan-glucosaminemyo-inositol oligosaccharide, and (iii) a ceramide tail attaching the GPI anchor to the cell membrane. (Data from reference $\underline{86}$ ). 


\section{Biosynthesis of Mannan and Other Decorating Polysaccharides}

The yeasts $S$. cerevisiae and C. albicans have an outer layer of proteins that are highly glycosylated with $\alpha$ and $\beta$-linked oligomannosyl residues by mannosyltransferases that use GDP-mannose as a substrate. $\mathrm{N}$-glycans are the major form of mannoprotein modification and consist of a core structure, which is similar in all eukaryotes and is further elaborated in the Golgi to form an outer chain comprising a linear $\alpha-(1,6)$ mannan backbone that is highly branched with $\alpha-(1,2)$ - and $\alpha-(1,3)$ containing side chains $(\underline{54}, \underline{55})$. In some species these may be further modified with mannosyl phosphate that may contain $\beta-(1,2)$ mannan. O-Linked mannans of fungi tend to be short, linear chains composed of $\alpha$-linked mannose sugars. In A. fumigatus and other molds, long mannan chains are also bound to core polysaccharides (9), and mannosyl groups also form part of GPI anchors. Although the mannan structural organization of fungi can differ substantially, a comparative genomic study has indicated that orthologues of most yeast mannosyltransferase genes can be found in the genome of A. fumigatus and other filamentous molds, although other branched chain mannans do not seem to be represented in the genome of Pneumocystis and possibly other fungi (56). In A. fumigatus, deletion of 11 genes coding for putative mannosyltransferases had little effect on the growth or physiology of A. fumigatus (57).

The synthesis of other decorating polymers remains less well understood. For example, in the case of $\alpha-(1,3)$ glucan synthesis, only the genes encoding putative $\alpha-(1,3)$ glucan synthases have been identified $(13,58)$. They are the largest known genes $(\sim 8 \mathrm{~kb})$ involved in cell wall polysaccharide synthesis and are characterized by two putative hydrolase and synthase domains separated by a single transmembrane domain. Deletion of a single $\alpha-(1,3)$ glucan synthase gene (NcAGS-1) or multiple genes (AGS1, AGS2, and AGS3) generates defects in the conidial cell wall in Neurospora crassa and A. fumigatus, respectively (59, 60), without impacting the growth of the vegetative mycelium. Deletion of the three AGS genes in A. fumigatus also resulted in attenuation in virulence in a mouse aspergillosis model. Similarly, genes involved in $\beta-(1,6)$ glucan synthesis have been identified based on the resistance of mutants to the K1 killer toxin, which kills yeast by binding to $\beta-(1,6)$ glucan (61). Many of these KRE genes such as KRE2, KRE5, KRE6, and KRE9 impact glucan synthesis without being directly associated with an enzymatic activity $(9,62)$. Permeabilized $S$. cerevisiae cells are capable of synthesizing $\beta-(1,6)$ glucan when supplied with UDPglucose, and the amount of product was reduced in the absence of Kre5 or Kre9 (61, 63-65). Deletion of KRE5, KRE6, or SKN1 in C. neoformans provided evidence that these genes are also involved in $\beta-(1,6)$ glucan synthesis in this pathogen and that the mutations also affected capsule formation, chitosan levels, and retention of cell wall mannoproteins (66).

In A. fumigatus, the UDP-glucose 4-epimerases Uge3 and Uge 5 are required for synthesis of UDP-galactopyranose. Galactofuran side chains of GM are synthesized by the sequential action of the UDP galactose mutase Ugm1 and the galactofuranosyltransferase Gfsa. More recently, a cluster of genes has been implicated in the biosynthesis of the galactosaminogalactan GAG in A. fumigatus (67). This cluster contains the ADG3 gene encoding a protein with a deacetylase domain, which deacetylates GAG, giving it polycationic properties, which are required for it to adhere to the hyphal surface and for biofilm formation. GAG has been shown to be an important virulence factor of $A$. fumigatus responsible for conidial adherence to epithelial cells as well as man-made surfaces $(68,69)$, with anti-inflammatory effects in mice ( $\underline{70})$.

\section{Melanin}

Melanins are negatively charged hydrophobic pigments of high molecular weight that are composed of polymerized phenolic or/and indolic compounds $(\underline{71}, \underline{72})$. Little is known about the detailed structure of melanin mainly because of the lack of suitable technologies to analyze amorphous, insoluble materials that are resistant to harsh chemical treatments. Indeed, most of the structural information about melanin comes from molecular studies deciphering the melanin metabolic pathways. Two main types of melanin are found in the fungal cell wall: the DHN-melanin of Aspergillus species and black fungal pathogens such as W. dermatitidis or Sporothrix schenckii and the 3,4-dihydroxyphenylalamine (DOPA)-melanin found in C. neoformans. Enriching growth medium with L-DOPA has even been shown to induce melanin production in C. albicans (73). A third form of water-soluble pyomelanin whose functional significance is less clear also exists in some fungi and bacteria.

Melanin in C. neoformans is synthesized by a laccase located in the outer layer of the cell wall in the presence of DOPA. A model structure has been established in which the concentric melanin layers in the wall come from irregularly shaped melanin granules. The spaces between granules would determine the size of the pores 
Gow et al.
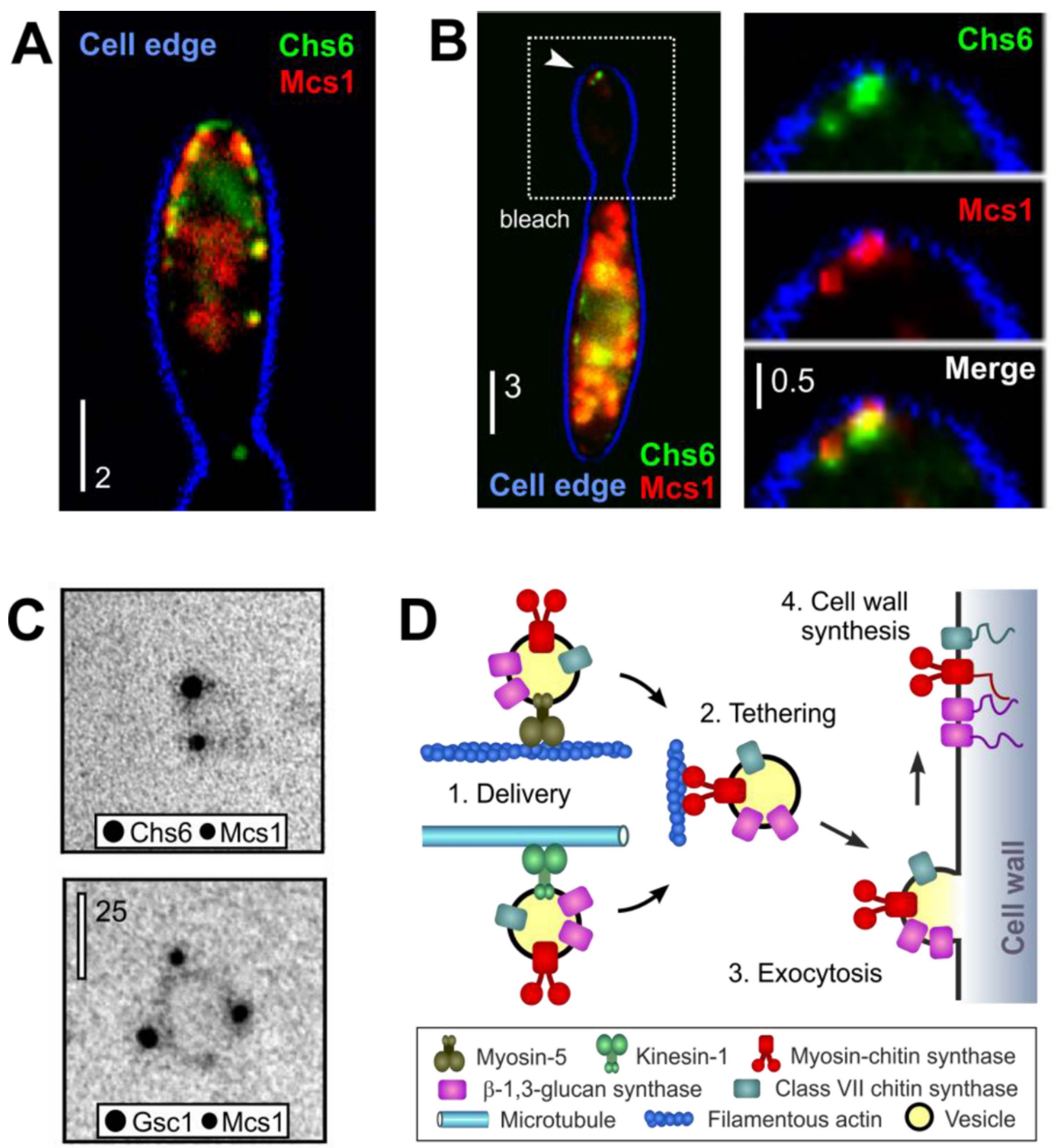

FIGURE 3 Glucan synthase (Gsc1), chitin synthase (Chs6), and myosin chitin synthase (Mcs1) of $U$. maydis are codelivered on the same secretory vesicles and colocalize at bud and hypha tips. (A) mCherry3-Mcs1 (red) and Chs6-GFP3 (green and yellow) colocalized Mcs1 and Chs6 at the bud tip. Scale bar, $2 \mu \mathrm{m}$. In (B) the bud is photobleached with a laser, and the codelivery of mCherry3-Mcs1 (red) and Chs6-GFP3 (green) into the photobleached bud is revealed after 5 minutes. Scale bars, $3 \mu \mathrm{m}$ (left) and $0.5 \mu \mathrm{m}$ (right). (C) Electron microscopy of secretory vesicles that have been colloidal-gold-labeled with antibodies showing Chs6 and Mcs1 colocalization in a single vesicle. Scale bars: $100 \mathrm{~nm}$. (D) A model for the delivery and secretion of vesicles containing both Chs6 and Msc1 via actin- and microtubule-based cytoplasmic transport systems to the apical cell membrane. After fusion with the apical membrane, the nascent polysaccharide chains of chitin and $\beta-(1,3)$ glucan are inserted into the cell wall-a process that anchors the synthases in situ, ensuring coordinated synthesis and tethering at the biosynthetically active apical region of the cell. (From Schuster et al. [45], with kind permission and modification by Gero Steinberg.)

controlling the passage of different secreted molecules (74). In addition, solid-state nuclear magnetic resonance data have identified a putative covalent linkage between melanin and mannose-containing polysaccharide motifs, suggesting that melanin may be anchored to the cell wall via linkages with galactoxylomannan or mannosylated proteins. Other work also suggests associations of melanin with chitin or chitosan $(\underline{73}, \underline{75})$.

DHN-melanin (named from one pathway intermediate 1,8-dihydroxynaphthalene) is formed from malonyl- 
CoA by the action of several enzymes including a polyketide synthase and several reductases and dehydratases. Deletion of the genes encoding the polyketide synthase (alb1 = pksP) of A. fumigatus, the initial step in the pathway, results in the production of conidia with a variety of different colors (76). In contrast to DOPAmelanin, no microstructure of cell wall-associated DHNmelanin has been obtained. Nor is it understood how the putatively intracellularly synthesized melanin crosses the cell wall barrier to become immobilized on the conidial surface. In addition, DOPA-melanins can be formed by Aspergillus and other black fungi $(77,78)$. Based on studies of plant pathogenic fungi, it can be predicted that the structural role of melanin in human fungal pathogens is to increase cell wall rigidity, enabling hyphae of black fungi such as $W$. dermatitidis to penetrate host tissues and pigmented conidia of Aspergillus or yeast cells of Cryptococcus to remain turgid when desiccated.

\section{Cell Wall Proteins}

There are multiple classes of proteins in the cell wall of fungi, whose functions are diverse and sometimes species-specific. They can serve in modifying the properties of the wall, in adherence to surfaces, and in protecting the fungus from harmful environmental elements or disguising it from phagocytes.

\section{GPI proteins}

The complement of cell wall-associated proteins and, in particular, those predicted to be GPI-anchored appear to be rapidly evolving, with a number of species-specific proteins evident $(\underline{4}, \underline{79})$. Genome-wide analyses have been performed to predict all proteins that can be modified by the addition of a GPI anchor $(\underline{80}, \underline{81})$. While S. cerevisiae is predicted to have around 66 GPI proteins, many fungal pathogens have many more, with some Candida species having well over 100 predicted GPI proteins $(\mathbf{7 9}, \underline{80})$. Within this cohort in Candida are a number of families, such as the Als, Iff, Epa, Sap/yapsins, and Sod proteins. These families show marked variation both in the number of members and in the case of the Als and Iff families in the number of intragenic tandem repeats within family members between and within different species $(\underline{80}-\underline{82})$. Furthermore, many predicted GPI proteins are species-specific, with no known orthologues $(\underline{80})$. Whether the diversity among the surface proteins has consequences in terms of relative pathogenicity of the different species remains to be firmly elucidated, because many species-specific GPI proteins have unknown functions.
In C. albicans, many of these CWP genes are highly regulated at the transcriptional level. Some are regulated during yeast-to-hypha morphogenesis, during the response of $C$. albicans to various environmental changes and stresses and, presumably, in vivo during the establishment of C. albicans infections (3). Non-gel proteomics using tandem liquid chromatography-mass spectrometry/mass spectrometry is now providing a global view of the cell wall proteome. It is possible not only to detect which proteins are cell-wall-localized ( $\underline{82}$, 84) but also to quantify them (프). This approach has identified 15 to 21 cell wall proteins on the surface of C. albicans when grown under rich laboratory culture conditions. Altering the environmental conditions such as carbon source, iron limitation, or hypoxia has a direct effect on the cell wall proteome composition and the abundance of certain wall proteins ( $\underline{86}-\underline{88})$. We still have little knowledge of cell wall protein expression, both quantitative and qualitative, during infection. Although many cell wall proteins are known to be immunogenic and hence likely to be expressed in vivo and to play roles in adaptive immunity, their significance in growth and pathogenesis is not known (9).

In most natural situations, the outer cell wall is impregnated with, or loosely attached to, a greasy outer layer of cell wall-associated proteins, sometimes called "moonlighting proteins." Much has been made of the apparent conundrum that these proteins are predominantly of cytoplasmic origin such as enolase, collagen, translation elongation factors, and certain heat shock proteins, which do not have a signal sequence for export across the cell membrane $(\underline{86}, \underline{90}, 91)$. Such proteins are readily removed by extraction protocols using SDS and reducing agents such as $\beta$-mercaptoethanol and dithiothreitol, which had been thought mild enough to preserve the integrity of the cell (91). However, it has been demonstrated that such treatment may partially solubilize the membrane, leading to the leakage of cytosolic contents (91). Biotinylation of cell wall proteins can also potentially permeabilize the cell membrane at moderate temperatures (91). Therefore, the likelihood is that most of these cell wall-associated proteins leak out of cells and become incorporated at the cell surface when cells are treated with reagents that semipermeabilize the cell membrane.

It is clear that the cell walls of fungi such as C. albicans have a significant capacity to absorb soluble proteins from the environment and that fungal surfaces are normally contaminated with cytoplasmic proteins that are picked up from the environment. Alternatively, it is possible that exosomes (secreted vesicles that transit in- 
tact through the cell wall) deliver cytoplasmic proteins to the surface, bypassing the normal secretory pathway (92). Once deposited on the cell surface, some of these proteins can impart important properties such as the binding of plasminogen and other host proteins (93), or opsonization, and could therefore have a direct effect on the function of the cell wall. In C. albicans, the hydroperoxide peroxidase-like protein Tsa1p is bound specifically to hyphal cells despite being expressed at approximately equal concentrations in yeast and hyphal cells $(90,94)$. This suggests that different cell surfaces are differentially receptive to protein binding and that the composition of cell wall-associated proteins could vary substantially between and within species and different cell types.

\section{Transglycosidases}

While most of the cell wall biosynthetic processes occur in the Golgi and at the cell membrane, part of the biosynthesis of the fungal cell wall takes place within the wall itself. Neosynthesized polysaccharides are linear or amorphous and become cross-linked to other polysaccharides by transglycosidases that are putatively anchored to the PM or located in the cell wall space to form the rigid three-dimensional network typical of the cell wall (Fig. 2B,C). The first transglycosidase identified as contributing to cell wall organization is a GPI-anchored enzyme encoded by the genes GEL and PHR in Aspergillus and Candida and GAS in Saccharomyces that splits internally a $\beta-(1,3)$ glucan molecule and transfers the newly generated reducing end to the nonreducing end of another $\beta-(1,3)$ glucan molecule $(95,96)$ (Fig. 2B). The generation of a new $\beta-(1,3)$ linkage between the acceptor and donor molecules results in the elongation of $\beta-(1,3)$ glucan chains. Transglycosidases that play such an essential role in branching and cross-linking polysaccharides should be common to all fungal species. Comparative genomic and proteomic analyses of ascomycete fungal species have identified six families of conserved, GPI proteins: Sps2, Gas/Gel, Dfg, Plb, Crh, and Yps $(79,96)$. The Sps2 and Dfg5 families are involved in cell wall construction, and the Crh family is involved in cross-linking $\beta-(1,6)$ glucan and chitin (97-99).

\section{Cell wall hydrolases and deacetylase plasticizing the rigid cell wall}

There is clear evidence that endo $\beta-(1,3)$ glucanases and chitinases participate in cytokinesis since mutations in these genes and inhibitors of these enzymes affect the separation of mother and daughter cells $(100,101)$. In filamentous fungi, which do not undergo cytokinesis, some models of cell wall synthesis invoke a delicate balance between cell wall synthesis and hydrolysis at the hyphal apex (102). However, there is no unequivocal evidence that cell wall hydrolases are required for tip growth, and mutants in C. albicans and A. fumigatus with single and multiple mutations in chitinase and endo $\beta-(1,3)$ glucanase genes do not appear to differ in growth rate or hyphal morphogenesis $(103,104)$.

Similarly, in zygomycetes, ascomycetes, and basidiomycetes substantial deacetylation of chitin to chitosan occurs, creating a more flexible molecule that becomes resistant to chitinases. Chitin deacetylase genes have been identified, but in general, their role in fungal morphogenesis is not clear yet. In C. neoformans, disruption of all three chitin deacetylase genes (105) attenuates virulence and results in a defect in cell wall integrity. In plant pathogens, chitin deacetylation can prevent plant receptors from recognizing chitin of plant pathogens (see below).

\section{Yapsins}

The yapsins play important roles in cell wall remodeling and in maintaining a robust cell wall. They comprise a subset of the aspartyl proteinase family, and in contrast to other members that are secreted, they are tethered to the membrane and the wall via the addition of a GPI anchor. The cell wall-localized proteolytic activity of ScYps1 was shown to be $\mathrm{pH}$-regulated, and it was shown that Yps1 acted as a "sheddase," releasing a number of GPI proteins from the wall-notably itself and Gas1 (106). In C. albicans, deletion of both the yapsin genes $S A P 9$ and $S A P 10$ resulted in reduced adherence to epithelial cells and in a reduction in epithelial damage in a reconstituted human epithelial model of oral infection (107). Similarly, Candida glabrata has a family of eight yapsins that have been implicated in virulence as well as in maintenance of cell wall integrity (108).

\section{Adhesins}

One vital property of the fungal cell wall that promotes virulence is adhesion to host cells and tissues. Several cell wall proteins have adhesin-like properties $(\underline{86}, 109)$. The best characterized are the C. albicans Als family of eight proteins (110) and the C. glabrata Epa family (111), both comprising GPI proteins. A more extensive family of GPI-anchored adhesin-like proteins has been identified in C. glabrata (112). Both the Als and Epa families have a characteristic domain organization with $\mathrm{N}$-terminal adhesin domains that impart specificity of host protein/glycan binding to different family members 
(113-116). The C. albicans hyphal-specific cell wall protein Hwp1 aids adherence to oral epithelial cells by acting as a substrate for host transglutaminases (117). Both Hwp1 and the Als family play significant roles in biofilm formation, and complementary binding between these adhesin types enhances the attachment of C. albicans cells to each other during biofilm generation (118). Interestingly, in pathogenic molds, proteins do not seem to act as adhesins, and this role seems to be a function of cell wall $\alpha-(1,3)$ glucans and GAG $(\underline{67}, \underline{69})$.

In C. albicans, a number of other cell wall proteins have also been shown to contribute to biofilm formation, including Eap1 (119), Sun41 (120-122), and members of a family that contains a CFEM-like domain (Rbt5, Pga10/Rbt51 and Csa1/Wap1) (123).

\section{Hydrophobins}

Hydrophobins form a class of amphipathic proteins that can self-assemble to form rodlets, generating a hydrophobic interface between filamentous fungi and their environments (124). The rodlets resemble amyloid fibrils and form a monolayer around aerial structures such as hyphae and fruiting bodies, coating hydrophilic surfaces to make them hydrophobic $(\underline{18}, \underline{19})$. Hydrophobins play roles in morphogenesis, may be developmentally regulated (125), and are also involved in adhesion of fungal cells to surfaces and hence have been associated with virulence of fungal plant and insect pathogens (126128). In human pathogens only RodA and RodB, the hydrophobins present on the A. fumigatus conidial surface, have been characterized in detail (19). RodA contributes to pathogenesis by protecting conidia from alveolar macrophage killing (20). This rodlet layer has also been shown to be an immune-shield masking the detection of conidia or a range of molds by macrophages and dendritic cells (21). Detection only occurs once the spores swell and germinate-a process that leads to cracking of the hydrophobin layer and hence revealing of the underlying immunologically active glucans.

\section{REGULATION AND SIGNALING}

\section{The Cell Wall Salvage Response}

The cell wall can be built in different ways depending on environmental conditions and exposure of agents that induce cell wall damage. The integrity of the $\beta-(1,3)$ glucan-chitin cell wall scaffold must be monitored and regulated constantly to enable growing walls to remain plastic enough to allow turgor-driven cell expansion yet robust enough to prevent bursting of the cell. It is not fully understood how this delicate balance between the rigidity and the compliance of the cell wall is maintained, but it is known that the nascent cell wall at the hyphal apex is thinner, has less hydrogen bonding between the antiparallel $\alpha$-chitin chains, and has fewer cross-links between chitin and $\beta-(1,3)$ glucan than the mature wall of the parallel sides of the hypha (102).

Regulation of cell wall biosynthesis occurs at many levels ranging from availability of substrate for biosynthetic enzymes to protein phosphorylation. A number of signaling pathways have been implicated in the regulation of cell wall biosynthesis and in the maintenance of a robust wall (Fig. 4). The pathways often impinge on different elements of the same promoter, allowing finetuning of gene expression.

The key pathway that controls cellular integrity via maintenance of the cell wall is the protein kinase C pathway (129) (Fig. 4). Best characterized in S. cerevisiae, this pathway is conserved in most fungal species, including human pathogens (130). Highly glycosylated integral membrane sensors, Mid2, Wsc family, and Mtl1, sense perturbations in the cell wall, and ScWsc1 has been shown to act as a nano-spring detecting wall stretching to trigger a response by activating Rho1. This GTPase relays signals to protein kinase $\mathrm{C}(\mathrm{Pkc} 1)$ and also regulates actin polymerization, polarized secretion, and glucan synthesis (129). Pkc1 lies at the top of a mitogen-activated protein kinase (MAPK) cascade and phosphorylates the Bck1 MAPKKK in addition to a number of other substrates, including chitin synthase (41). The signal passes down the MAPK cascade via a phosphorylation relay and ultimately activates transcription factors that regulate target gene expression.

Other pathways that play significant roles in the regulation of cell wall biosynthesis are the $\mathrm{Ca}^{2+} /$ calcineurin pathway; a second MAPK cascade, the HOG pathway; and the $\mathrm{pH}$-sensing RIM101 pathway (131). Activation of cell wall compensatory or salvage mechanisms often results in elevated chitin levels in the cell wall and an increase in the number of GPI proteins that are covalently attached to chitin rather than $\beta-(1,3)$ glucan, reflecting significant alterations to cell wall architecture (132). Transcript profiling experiments in S. cerevisiae in various cell wall mutant backgrounds and in cells treated with cell wall perturbing agents have identified a core set of regulatory genes including Rlm1, Crz1, SBF (Swi4/ Swi6), Msn2/Msn4, Ste12, and Tec1 that are activated upon cell wall assault (133). Some orthologous genes have also been identified as upregulated in C. albicans in response to caspofungin $(\underline{134}, \underline{135}), \mathrm{Ca}^{2+}(\underline{136})$, and cell wall mutations. 


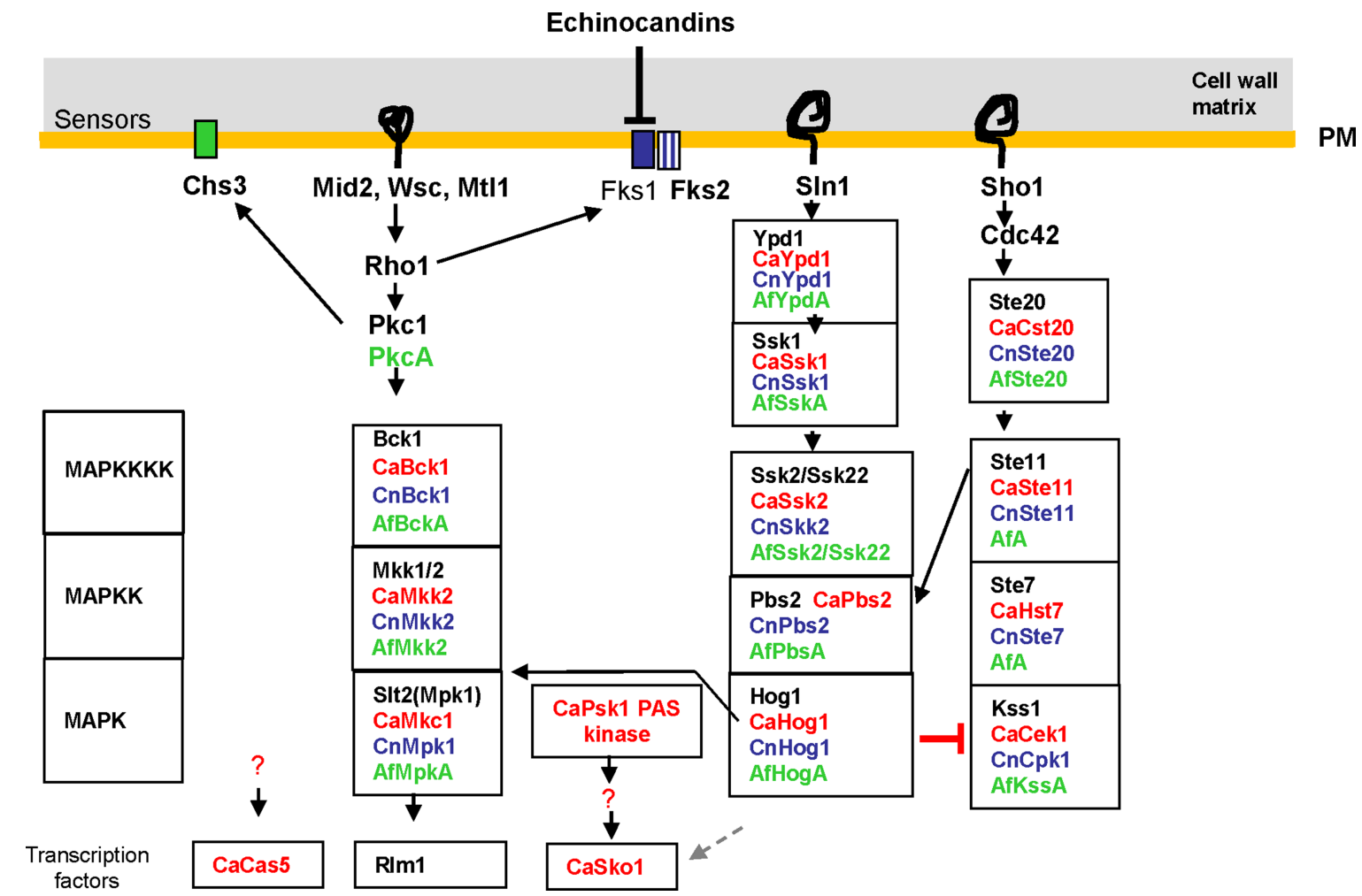

FIGURE 4 Signaling pathways that regulate cell wall remodeling and cell integrity. Integral, glycosylated, membrane sensors (Wsc family, Mid2, Mtl1, Sho1, and Sln1) detect specific perturbations in the wall and transduce the signal to the downstream pathway elements that feed into MAP kinase cascades. Transcription factors at the bottom of the pathway activate gene expression to promote remodeling of the cell wall architecture to maintain cell integrity. In S. cerevisiae, Pkc1 is involved in targeting Chs3 to the plasma membrane in response to heat shock, and Rho1 activates the Fks1 subunit of $\beta-(1,3)$ glucan synthase. Black text denotes $S$. cerevisiae proteins; red, $C$. albicans; blue, C. neoformans; and green, $A$. fumigatus. The fungal pathogen orthologues may not have been fully characterized, and their position in the pathways reflects the $S$. cerevisiae paradigm. However, significant rewiring of signaling pathways is evident in C. albicans; for example, the role of the CaSko1 transcription factor in response to caspofungin is independent of the Hog1 MAP kinase (135) but involves the Psk1 PAK kinase. Furthermore, in C. albicans, there is no evidence of Ste11 activating Hog1 like there is in S. cerevisiae (213). In C. albicans, the Cas5 transcription factor also contributes to the transcriptional response to caspofungin, and there are no Cas5-orthologues in S. cerevisiae (134). The CaCek1 MAP kinase is also implicated in cell wall remodeling and is constitutively activated in a hog1 null mutant background (213). Fungal pathogen orthologues of the elements upstream of the MAP kinase cascades are not shown but exist, although the membrane sensors appear to have significantly diverged. Exogenous calcium enters cells primarily through the Cch1/Mid1 channel complexes. A third $\mathrm{Ca}^{2+}$ channel, Fig1, plays a role in $\mathrm{Ca}^{2+}$ transport during mating, but no orthologues of Fig1 have been identified in $C$. neoformans or A. fumigatus. $\mathrm{Ca}^{2+}$ binds to and activates calmodulin ( $\left.\mathrm{Cmd1}\right)$, which in turn activates the phosphatase calcineurin, composed of a catalytic (Cna1) and a regulatory (Cnb1) subunit. S. cerevisiae has two $\mathrm{Cna1}$ isoforms (Cna1/Cmp1 and Cna2/Cmp2). Calcineurin activates the transcription factor Crz1 by dephosphorylation to induce expression of genes that contain calcium-dependent response elements within their promoter sequences. No Crz1 orthologue has been identified in $C$. neoformans. Some data also suggest that calcineurin has regulatory functions that are independent of Crz1 (136). Several of the A. fumigatus proteins that may be related to this pathway remain unannotated, so putative orthologs have been ascribed but have not been experimentally validated. The pathway can be blocked via FK506 binding to Fpr1 or cylosporin A binding to cyclophilin Cpr1, and both interactions result in calcineurin inhibition. (Adapted from references 129, 130, 214-216). 
Activation of cell wall salvage pathways, specifically the protein kinase $\mathrm{C}$ pathway, is one of the responses to sublethal doses of the echinocandin antifungal drugs (137, 138). Synergism has also been shown between immunosuppressive drugs that block the $\mathrm{Ca}^{2+} /$ calcineurin pathway (FK506, cyclosporine A) and the echinocandins in C. albicans, C. neoformans (139), and A. fumigatus (140). Mutants blocked in the protein kinase $\mathrm{C}$ pathway, $\mathrm{Ca}^{2+}$ calcineurin, and certain steps of the HOG pathway (but not Hog1) are hypersensitive to echinocandins (138, 140, 141). Echinocandin hypersensitivity has been used as a screen to identify signaling components that are involved in the response of C. albicans to this class of antifungal $(134,135)$. These screens identified a novel C. albicansspecific transcription factor, Cas5 (134), and Sko1, the transcription factor thought to be downstream of the Hog1 MAP kinase. Interestingly, Hog1p itself was not required for the echinocandin response via Sko1, but the Sko1dependent activation of genes induced by caspofungin was dependent on another protein kinase, Psk1 (135).

\section{Regulation of Septation}

Redundancy exists in the strategies employed to assemble the fungal cell wall under both normal and cell wall stress conditions (Fig. 5A). This is also evident in the observation in S. cerevisiae that a septum can be fabricated in mutants that lack enzymes that are required to make the normal septum. A greatly thickened salvage septum can be made by the Chs 3 enzyme in the absence of the ScChs2 chitin synthase that normally synthesizes the chitinous primary septum (33). In C. albicans, a septum can still be formed that permits cell division in a mutant that lacks both CaChs3 and CaChs1 (the orthologue of ScChs2), the normal chitin synthase machinery required for septation $(\underline{138}, 142)$ (Fig. 5B).

Three distinct types of salvage septa were identified in C. albicans that could be synthesized in the absence of Chs1 by different combinations of Chs2, Chs3, and Chs8 (142). An implication of this work is that all four chitin synthases in C. albicans can be employed for septum formation-a prediction supported by observations that $\mathrm{CaChs1,} \mathrm{CaChs} 2, \mathrm{CaChs} 3$, and $\mathrm{CaChs} 8$ are all located at the site of cytokinesis under normal conditions $(37,143)$. Similarly, all eight chitin synthases localize to the septa of Ustilago (143). In S. cerevisiae, the septum is assembled on a complex scaffold of proteins that are linked in turn to the septin rings (144) (Fig. 5A). This scaffold involves Bni4p, which tethers the Chs3 chitin synthase enzyme to the mother-bud neck by forming a bridge between a regulatory protein Chs 4 and the septin Cdc10. In C. albicans, BNI4 was shown not to be essential for chitin ring formation, but null mutants were affected in bud formation, suggesting that some, but not all, features of this scaffold are conserved between

FIGURE 5 Chitin synthesis and septum formation in yeasts. (A) Septation involves a protein scaffold that tethers the Chs3p chitin synthase that assembles the chitin ring to Cdc10p of the septin ring complex via Chs4p and Bni4p. (B) The structure of the wild-type septum of C. albicans (transmission electron microscopy image on right) is shown alongside septumless yeast cells in a chs1 chs3 conditional mutant (middle transmission electron microscopy image) and salvage septa (transmission electron microscopy image on left) made in the same mutant strain after stimulation of the cell wall salvage pathways by growth in the presence of calcium ions and calcofluor white. (Reused from reference 138 under CC BY 4.0).

A
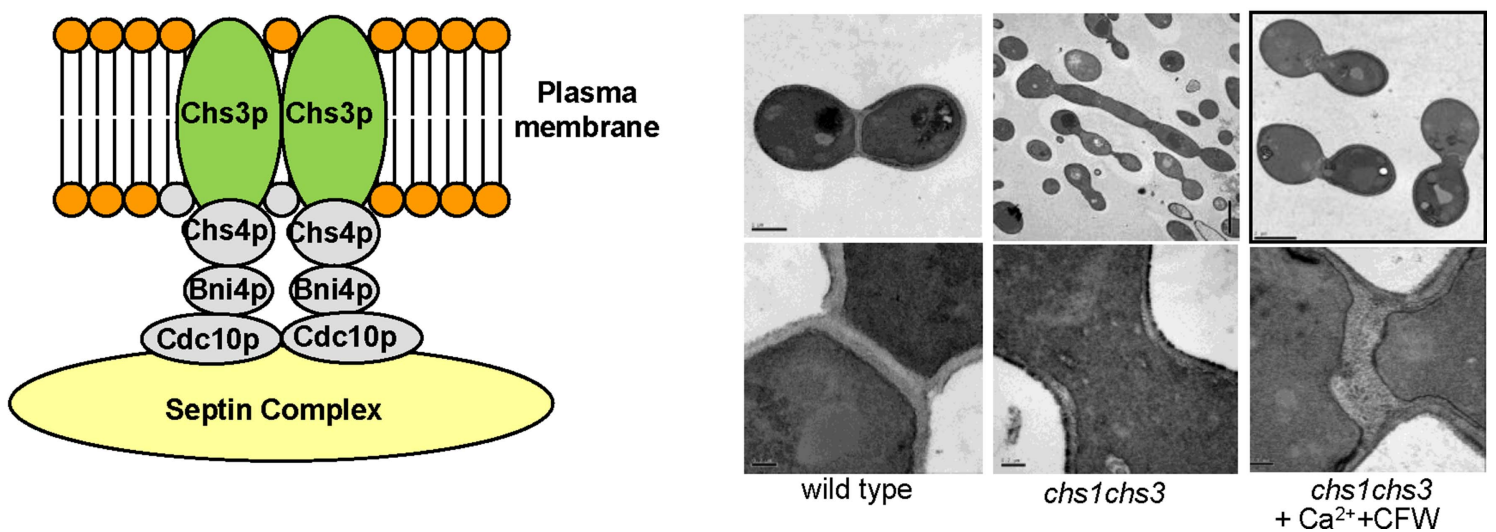
these two species (145). It remains to be established how the various salvage septa of fungi are constructed and how and whether they are assembled on a normal septin ring structure. Septins also play key roles in filamentous fungi. For example, they have been shown to play multiple roles in septation, conidiation, the function of clamp connections, and nuclear dynamics $(146,147)$.

Septation is a complex process tightly coupled to the cell cycle. The transcription factor Ace 2 regulates the expression of many genes that orchestrate the process of cytokinesis. Among these are chitinases and glucanases that in some fungi have been shown to aid the septation of daughter cells by digesting the interstitium of the wall between the completed septal structures $(100$, 148). Fks1 localization and activation require the Rho1 GTPase as a regulatory subunit (1). Chitin synthase phosphorylation may also be involved in regulating its localization throughout the cell cycle $(40,41)$, but the details of how chitin synthase and other cell wall biosynthetic genes are targeted in the cell cycle remain to be established.

\section{Regulation of Polarized Growth}

Polarized cell wall growth requires the concerted activity of the cytoskeleton and cortical patches of membrane proteins that regulate secretory vesicle traffic to the sites of cell wall growth (149-152). In filamentous fungi, cytoplasmic transport must move vesicles and organelles to the apex over long distances. In hyphae this transport occurs in two stages. Vesicles are delivered to the apical surface first via cytoplasmic transport, probably mediated by microtubules, to a vesicle supply center near the apex called the Spitzenkörper (apical body). Subsequently, docking and fusion with the PM are mediated by the "Arp2/3 complex," which organizes apical actin (151), and an "exocyst complex" which is responsible for vesicle docking and fusion (152). An additional group of apical proteins called the "polarisome," which contains the essential Cdc42 Rho GTPase, is responsible for recruitment of actin and other components required for polarized cell growth. This dynamic process therefore involves the secretory pathway, cytoskeleton function, and the activities of multimeric protein complexes that establish and maintain polarity. In filamentous fungi with chitin synthases that have an MMD, the MMD contributes to the docking process by retaining the enzymes in the apical dome (47). A detailed description of this integrated process is beyond the scope of this review but has been published elsewhere (138, 141-143). However, ultimately, the cell shape and growth of fungi relate to how the vectorial secretion of secretory vesicles is regulated and to the overall composition of the cell wall (152-155).

Most pathogenic fungi are dimorphic (sometimes polymorphic), and the prevailing morphotype existing in the environment is normally different from the invading form. Cell wall composition varies with morphotype, but data in this area are rather scarce. Universal relationships between morphology (for example, spherical or tubular) and cell wall structure and composition do not exist. In the yeast of C. albicans or the conidium of $A$. fumigatus, the amount of chitin is reduced in comparison to the mycelium. However, in Blastomyces dermatitidis or Paracoccidioides brasiliensis, the amount of chitin is lower in the mycelial form $(156,157)$ than in the yeast form. $\beta-(1,3)$ Glucan is higher in yeast of $P$. brasiliensis but lower in conidia of $A$. fumigatus than in their respective mycelial stages. $\beta-(1,3)$ Glucans are present in higher amounts in the conidia of $A$. fumigatus and almost absent in the yeast phase of $B$. dermatitidis and $P$. brasiliensis compared to their respective mycelial stages. $\beta-(1,3)$ and $\beta-(1,6)$ glucans are also absent in the biotrophic hyphae of the plant pathogen Colletotrichum (158). In Sporothrix schenkii, no difference in composition of the structural polysaccharides is seen between yeast and mycelial cell walls. For some fungi such as C. albicans, all morphotypes are hyaline; for others such as A. fumigatus, conidia are pigmented, whereas the mycelium is hyaline, and for black fungi such as W. dermatitidis, all morphotypes contain melanin. Links between morphology and cell wall composition are even more difficult to establish because cell wall composition is not only stage- and strain-specific but is also dependent on culture conditions (159).

\section{CELL WALL AS A TARGET Antifungal Target}

The cell wall is composed almost exclusively of molecules that are not represented in the human body yet are important or essential for fungal growth viability or virulence. As such, the wall is a near ideal target for the design of antifungal drugs for clinical use. Nikkomycins and polyoxins are specific chitin synthase inhibitors of chitin synthases, and although they often potently inhibit enzyme activity in in vitro assays, they are not efficiently taken up in vivo and consequently are often not effective antifungals (160).

The newest class of clinically used antifungals are the echinocandins, which are fungal secondary metabolites that inhibit $\beta-(1,3)$ glucan synthesis in the cell wall. Echinocandins have a cyclic hexapeptide core with a 
lipid side chain that is responsible for their antifungal activity and determines species specificity. Three compounds are in clinical use-caspofungin, anidulafungin, and micafungin-and new agents such as CD101 (Biafungin) are under development. These drugs have proven to be safe and effective, but they are insoluble drugs requiring intravenous administration. Clinical resistance has been shown to be due to the acquisition of point mutations in one of two hotspots in the outer face of the Fks1 $\beta$-(1,3) glucan synthase target protein, and the efficacy of the drugs can be offset by the induction of chitin synthesis in the cell wall (see above) $(161,162)$.

\section{Target for Mammalian Immune System}

In recent years it has been increasingly evident that there are conserved aspects in the ways both animals and plants detect and respond to fungal invaders. Indeed, defense mechanisms against fungal pathogens have been discovered in all higher organisms that have been investigated.

In humans and other mammals, the innate immune system has evolved to recognize conserved microbial structures called pathogen-associated molecular patterns (PAMPs) via a range of pattern-recognition receptors (PRRs) on their cell surfaces (Fig. 6). Detailed analyses of this recognition system for fungi have been extensively reviewed and are beyond the scope of this article $(\underline{7}, 163)$. However, recognition of the fungal cell wall ultimately results in the uptake and killing of fungal invaders by phagocytes and the induction of innate and adaptive immunity. Almost all of the main components of the fungal cell wall can be detected by immune cells, and there are more PRRs that detect fungus-specific PAMPs than for any other class of organism. Mannans and mannoproteins are recognized by mannose receptor and Toll-like receptor 4 (TLR4), phospholipomannan by TLR2, and $\beta$-mannosides by galectin-3 (163). $\beta$ - $(1,3)$ Glucan is recognized by the C-type lectin dectin-1 (163165 ), and chitin can be detected by the mannose receptor and by Nod 2 and TLR9 (Fig. 6). Chitin and chitosan have emerged as important immmunoreactive polysaccharides, with chitin having anti-inflammatory properties, while chitosan is more proinflammatory in nature (166-168). Chitin isolated from Aspergillus was shown to have both pro- and anti-inflammatory properties depending on the presence of costimulatory PAMPs, and IgG-opsonized chitin was shown in this study to be recognized by a novel Fcy receptor-dependent mechanism (169). Chitin recognition is also complicated by the fact that particle size plays an important role in its ability to engage with receptors and induce the secretion of cytokines (170).
Dectin- 1 detection of $\beta-(1,3)$ glucan represents a major recognition mechanism by the immune system. This polysaccharide is often masked by the outer layers of the cell, resulting in shielding of $\beta-(1,3)$ glucan and escape of immune recognition (7). Various unmasking treatments, such as heat-killing, echinocandin treatment, or genetic deletion of superficial mannans or glucans of several fungal pathogens, have been shown to enhance signaling of leukocytes via dectin-1 (11, 171-173). In the architecture of fungal cell walls, superficial mannoproteins, $\alpha$-glucans, conidial spore hydrophobins, and melanin can all mask the exposure of $\beta-(1,3)$ glucan and thereby prevent dectin-1-mediated recognition (Fig. 1) (174). Fungal cell wall PAMPs can be detected singly or in combination by PRP complex leukocytes (175), and the relative importance of individual PAMPs is likely to vary substantially in different immune cell types. It is most likely that recognition of the fungal cell wall involves detection of multiple components of the cell wall that may vary according to fungal species and during different stages and different sites of clinical infections.

\section{Resisting immunity: Cryptococcus capsule}

More than 40 years ago, it was shown that encapsulated cryptococci are resistant to phagocytosis (176). Capsular polysaccharides are able to scavenge oxygenrelated oxidants as well as antimicrobial peptides that are essential for killing phagocyte effectors (177). However, the protective effect of the capsule varies with the phagocyte cell since a recent study shows that C. neoformans enters the endolysosomal compartment of dendritic cells and is killed by lysosomal components despite the presence of a capsule (178). However, it is clear that capsular polysaccharides play an essential role in escaping phagocytosis. Moreover, the enlargement of the capsule size associated with in vivo growth is essential for fungal survival and replication inside phagocytic cells. Recent observations have shown that C. neoformans, and other species of yeasts, can induce its own expulsion from the phagosome $(179,180)$. After the expulsive event, both the macrophage and the expelled C. neoformans continue to grow normally. This mechanism, which allows the pathogen to escape the phagocyte without triggering host cell death and subsequent inflammation, is entirely dependent on the presence of the capsule since acapsular cells do not promote phagosomal extrusion.

\section{Resisting immunity and stress: melanin}

Melanins are an adaptation of fungi to resist environmental stress. Melanized fungal cells resist extreme 


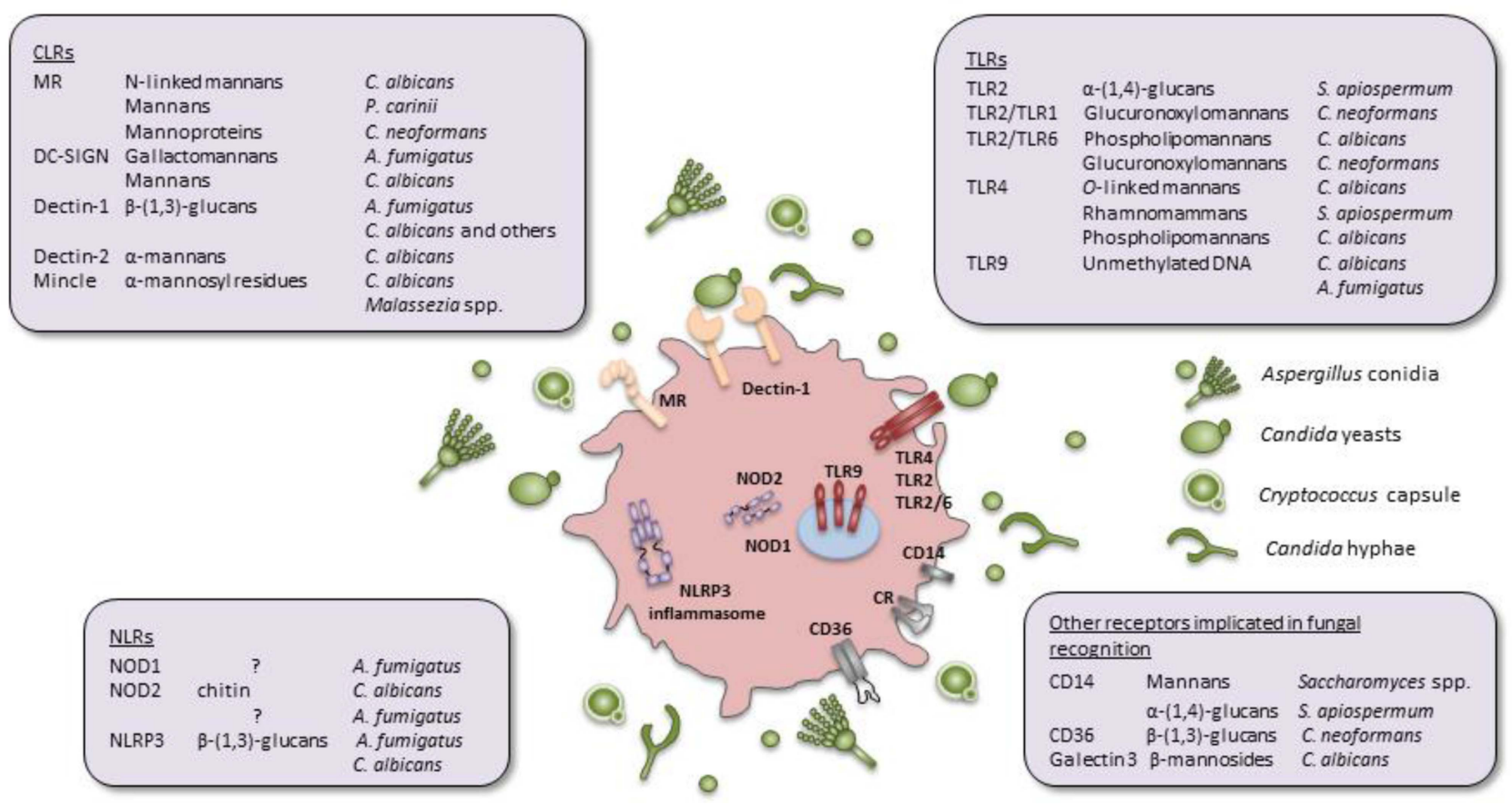

FIGURE 6 Recognition of human fungal pathogens. PAMP-PRR interactions for fungal cell recognition are shown as described in the text. Interactions with CLRs (C-type lectins), TLRs (Toll-like receptors), NLRs (Nod-like receptors), and a range of other receptors are shown in the purple boxes along with the relevant fungal PAMPs and examples of organisms for which given PRR-PAMP recognition phenomena have been described.

temperature and UV and ionizing radiation; indeed, melanized fungi in soils have been shown to be able to harvest energy from ionizing radiation for growth (181, 182). Melanin also binds to heavy metals or antifungal drugs, resulting in their detoxification. Internalization by phagocytes of C. neoformans, S. schenkii, or F. pedrosoi, but not Aspergillus, can be directly affected by the presence of melanin in the cells. Melanin also protects microbes from host defense reactions since albino strains are more susceptible to killing after phagocytosis. Resistance is due to quenching of nitrogen- or oxygen-derived radicals $(67)$ or microbiocidal peptides $(67,183)$. After phagocytosis, the only material left is the melanin ghost, confirming the extreme resistance of this compound not only to chemical treatments but also to immunological aggression. These data explain why melanin confers a survival advantage for the melanized morphotypes in the environment and especially to enzymatic degradation by the surrounding hostile microflora.

\section{Target for the Plant Immune System}

Plant immunology is now a well-established discipline, and it is clear that plants also recognize fungal PAMPs to trigger immunity $(\underline{8}, \underline{184}, \underline{185})$. Plant PRRs can be located on the plant cell surface or receptor-like proteins that bind fungal and other PAMPs of damage-associated molecules.

Recognition of chitin plays a major role in plant immunity to fungi. Two major chitin PRRs have been characterized. The chitin binding protein LysM-receptorlike protein CEBiP was first identified in rice, while in Arabidopsis, chitin-triggered plasmodesmatal closure is induced by LysM-receptor kinase LYK4 (모 184, 185) (Fig. 7). Plants and fungi have been engaged in an immunological arms race that mediates recognition and disguise of fungal chitin. Plant chitinase secretion can liberate chitin fragments that promote recognition. Reciprocally, some fungal pathogens synthesize $\alpha-(1,3)$ glucan or secrete effector molecules to block chitin recognition or chitinase-mediated attack $(186,187)$ (Fig. 7). Some fungi produce high-affinity chitin-binding effector scavengers that bind chitin and prevent its interaction with plant chitin receptors or block chitin-induced chitin receptor dimerization that is required for signaling. Some fungi convert chitin to chitosan to escape chitinase degradation and prevent recognition by chitin receptors of the plant immune response (Fig. 7) (188). 
An excellent example comes from a study of the hemibiotrophic plant pathogen Colletotrichum graminicola, which infects maize. The invading biotropic hyphae of this fungus coordinately downregulates GLS1, KRE5, and KRE6, resulting in the formation of hyphae with little or no exposed $\beta-(1,6)$ and $\beta-(1,3)$ glucan $(158,188)$. They also induce chitin deacetylation in the hyphal walls. As a result, the fungus can colonize the plant tissue without inducing PAMP-triggered immunity.

\section{Diagnostics and Immunotherapeutic Targets}

Promising vaccines and immunotherapies are under development that are mainly based on cell wall or cell wall-associated components (189-192). Examples that have been shown to be efficacious in mouse models of systemic mycoses include C. albicans vaccines based on the N-terminal regions of Als1 (193) and Als3 (194), synthetic glycopeptides that are based on epitopes of cell wall-associated proteins conjugated to mannose trisaccharides (195), and anti-Mp65 antibodies (196). Vaccination of mice with recombinant versions of the allergen Aspf3 protected mice from invasive aspergillosis (197). An antibody against GXM of the C. neoformans capsule conveys protection in animal models and has undergone phase I clinical trials (198). An antilaminarin [anti- $\beta-(1,3)$ glucan] monoclonal antibody can inhibit growth of A. fumigatus, C. albicans, and C. neoformans, suggesting that a single therapy of this type may be efficacious against a wide range of fungi (199-201).

Cationic antimicrobial peptides also play important roles in host defense against microbial pathogens including fungi (202) and have been shown to be important in the oral cavity, lungs, and GI tract. The action of salivary Histatin 7 is mediated through heat shock proteins Ssa1 and Ssa2 (203), which have been shown to be cell wall and membrane associated. Novel therapies based on antimicrobial peptides have much potential in the clinic and can be used, for example, to coat inanimate medical devices such as indwelling catheters

FIGURE 7 Recognition and avoidance of the recognition of chitin by plant pathogens. The detection of fungal chitin is used to trigger PAMP-mediated immunity in plants. To counter this, plant pathogenic fungi have evolved a range of mechanisms to avoid detection, including the following. (A) The liberation of chitin fragments by host chitinase attack can activate host immunity. (B) Countering this, some phytopathogens secrete effectors that block access to chitinase or (C) inhibit chitinase activity. (D) Fungal LysMtype effectors block recognition either by tight binding to prevent engagement with the host PRR or by interfering with host receptor dimerization. (E) The synthesis of an outer cell wall layer of a- $(1,3)$ glucan (as in certain human pathogenic species) prevents chitinase action and access to inner cell wall PAMPs. (F) Some fungal pathogens convert, to a greater or lesser extent, chitin into chitosan by inducing chitin deacetylases. This modified form of chitin is a poor substrate for chitinase and only weakly induces plant immune recognition. (From Bart Thomma with permission [adapted from reference 186]).

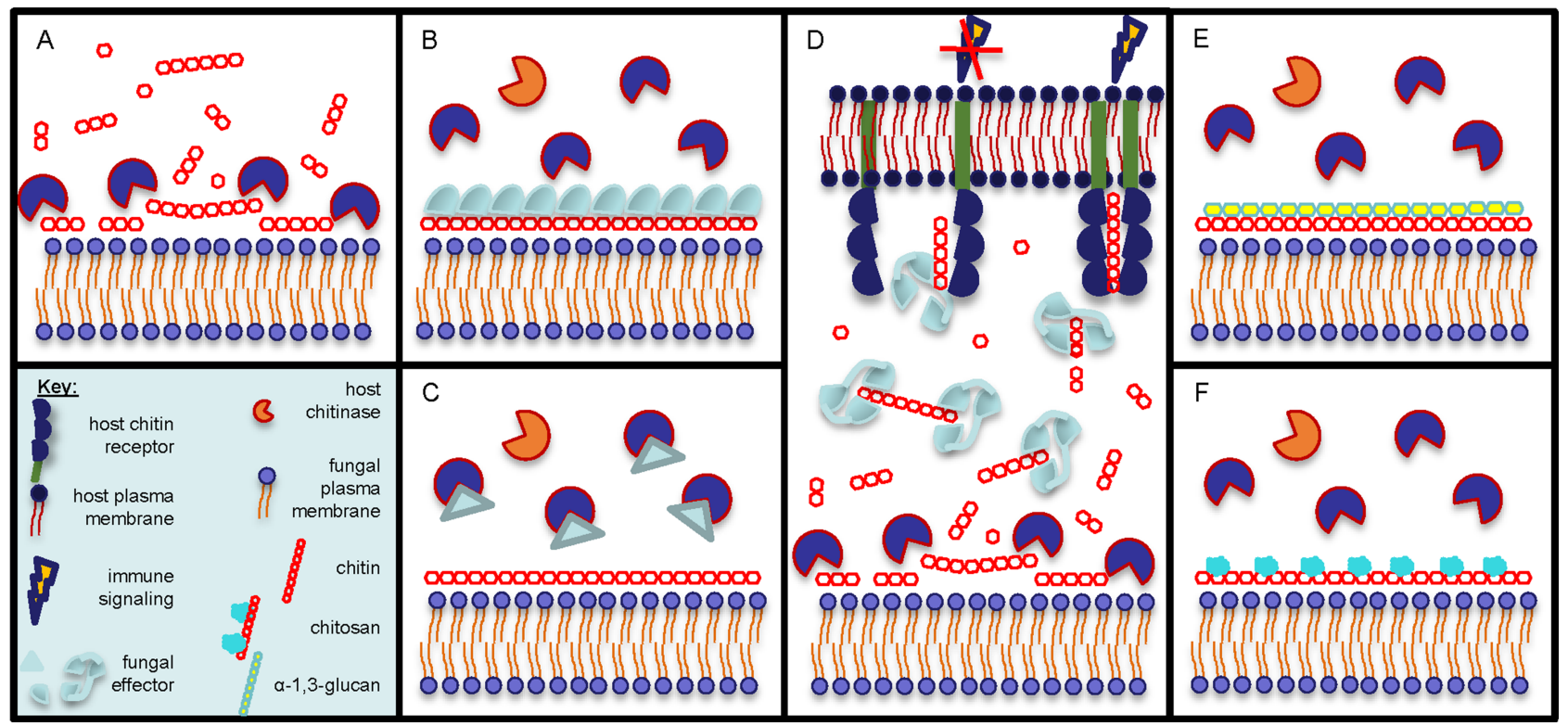


to prevent microbial biofilm formation, one of the risk factors associated with invasive fungal infections (204).

\section{Diagnostic Antigens}

Cell wall polysaccharides have formed the basis of the development of serological tests for the diagnosis of systemic fungal infection since their presence in the biological fluids of infected immunocompromised patients is directly correlated to fungal growth. An increase in the circulating antigen results from expanded fungal growth synonymous with a worsening of the disease, whereas successful antifungal therapy or immune reconstitution is associated with a reduction in antigen concentration. Galactomannan, mannan, and glucuronoxylomannan are the specific cell wall polysaccharides of interest for the diagnosis of aspergillosis, candidiasis, and cryptococcosis, respectively.

A monoclonal antibody directed against galactofuranose residues is used for the diagnosis of aspergillosis (205). The sensitivity of the commercially available sandwich enzyme-linked immunosorbent assay test is very high (on the order of nanograms per milliliter). This is due to the presence of epitopes not only on the cell wall polysaccharides but also on glycoproteins and glycolipids of Aspergillus species. This MAb recognizes $\beta-(1,5)$ linked galactofuranose residues but also terminal Galf $\beta$ - $(1,2)$ linked to mannan of $N$-glycans (206).

Identifying the presence of both $\alpha$ - and $\beta$-mannan increases the specificity and sensitivity of candidemia diagnosis. In the case of candidiasis, parallel monitoring of circulating mannan and antimannan antibodies can be performed. A decrease in antibody titer often correlates with an increase in antigen detection $(207,208)$.

Polyclonal antibodies have been raised against a mixture of complex capsular polysaccharides (GXM) of $C$. neoformans to develop EIA or latex agglutination tests able to recognize all serotypes of this fungal species (209).

A test for the detection of $\beta-(1,3)$ glucan has also been developed using a modification of the Limulus proteolytic cascade identifying a $\beta-(1,3)$ glucan as an ancestral innate defense reaction undertaken by arthropods. The sensitivity of this test is very low since it can detect 10 to $50 \mathrm{pg}$ of $\beta-(1,3)$ glucans/ml $(\underline{210}, 211)$. All these tests, however, have associated problems with false positives and negatives, insufficient early detection in comparison with clinical signs, and interaction with serum proteins including antibodies that require a proteolytic or EDTA treatment of the serum. In addition, the exact composition of the antigens produced in vivo as well as an understanding of the antigen secretion process is often unknown $(62,212)$.

\section{CONCLUSIONS}

The cell wall represents a major organelle of the fungus, determining viability, shape, and interactions with the environment. The assembly of the cell wall involves more than a thousand genes that encode a complex network of metabolic, signaling, and biosynthetic functions. Recent research has shown that redundant pathways exist to activate cell wall salvage mechanisms under conditions of cell wall damage and that the assembly of the wall can be modified and adapted to cope with stress. Although the walls of most fungi have a common skeleton, they also comprise a huge diversity of specialized molecules that are attached to the skeleton that define their specific ecologies. A range of mechanisms exist that ensure that the surface characteristics of the wall are hugely variable, and indeed, it is likely that no two cell walls that are identical have ever been assembled in any fungus. For fungal pathogens, the cell wall remains an ideal yet somewhat unrealized target for chemotherapy since its enzymology is fungus-specific. Similarly, the unique set of fungus-specific polysaccharides and glycoproteins that compose the outer and inner cell wall layers represent fungus-specific pattern recognition molecules and antigens that stimulate immune function of animals and plants. However, the inherent variability of the cell wall means that it is a moving target for both antifungal chemotherapy and for immune surveillance, and a raft of immune recognition avoidance mechanisms has evolved for both plant and animal pathogens that drives a "detect-or-escape" arms race between the host and pathogen.

\section{ACKNOWLEDGMENTS}

N.G. is funded by the Wellcome Trust via a senior investigator award and a strategic award and by the MRC Centre for Medical Mycology. C.M. acknowledges the support of the Wellcome Trust and the MRC. N.G. and C.M. are part of the MRC Centre for Medical Mycology. J.P.L. acknowledges support from ANR, Aviesan, and FRM.

\section{REFERENCES}

1. Lesage G, Bussey H. 2006. Cell wall assembly in Saccharomyces cerevisiae. Microbiol Mol Biol Rev 70:317-343 http://dx.doi.org/10.1128 IMMBR.00038-05.

2. de Groot PW, Ruiz C, Vázquez de Aldana CR, Duenas E, Cid VJ, Del Rey F, Rodríquez-Peña JM, Pérez P, Andel A, Caubín J, Arroyo J, García JC, Gil C, Molina M, García LJ, Nombela C, Klis FM. 2001. A genomic approach for the identification and classification of genes involved in cell wall formation and its regulation in Saccharomyces cerevisiae. Comp Funct Genomics 2:124-142 http://dx.doi.org/10.1002 lcfg.85.

3. Lombard V, Golaconda Ramulu H, Drula E, Coutinho PM, Henrissat B. 2014. The carbohydrate-active enzymes database (CAZy) in 2013. Nucleic Acids Res 42(D1):D490-D495 http://dx.doi.org/10.1093/nar /gkt1178. 
4. Coronado JE, Mneimneh S, Epstein SL, Qiu WG, Lipke PN. 2007. Conserved processes and lineage-specific proteins in fungal cell wall evolution. Eukaryot Cell 6:2269-2277 http://dx.doi.org/10.1128/EC.00044 $\underline{-07 .}$

5. Money NP. 2001. Biomechanics of invasive hyphal growth, p 3-17. In Howard RJ, Gow NAR (ed). The Mycota, vol. VIII. Springer-Verlag, Berlin, Germany.

6. Money NP. 2008. Insights on the mechanics of hyphal growth. Fungal Biol Rev 22:71-76 http://dx.doi.org/10.1016/j.fbr.2008.05.002.

7. Erwig LP, Gow NAR. 2016. Interactions of fungal pathogens with phagocytes. Nat Rev Microbiol 14:163-176 http://dx.doi.org/10.1038 /nrmicro.2015.21.

8. Zipfel C. 2014. Plant pattern-recognition receptors. Trends Immunol 35:345-351 http://dx.doi.org/10.1016/j.it.2014.05.004.

9. Latgé JP. 2007. The cell wall: a carbohydrate armour for the fungal cell. Mol Microbiol 66:279-290 http://dx.doi.org/10.1111/j.1365-2958.2007 $.05872 . \mathrm{x}$.

10. Fleet GH. 1991. Cell walls, p 199-277. In Rose AH, Harrison FD (ed). The Yeasts, vol. 4. Academic Press, New York, NY.

11. Wheeler RT, Kombe D, Agarwala SD, Fink GR. 2008. Dynamic, morphotype-specific Candida albicans $\beta$-glucan exposure during infection and drug treatment. PLoS Pathog 4:e1000227 http://dx.doi.org/10.1371 journal.ppat.1000227.

12. Rappleye CA, Eissenberg LG, Goldman WE. 2007. Histoplasma capsulatum $\alpha$ - $(1,3)$-glucan blocks innate immune recognition by the betaglucan receptor. Proc Natl Acad Sci USA 104:1366-1370 http://dx.doi .org/10.1073/pnas.0609848104.

13. Beauvais A, Maubon D, Park S, Morelle W, Tanguy M, Huerre M, Perlin DS, Latgé J-P. 2005. Two $\alpha(1-3)$ glucan synthases with different functions in Aspergillus fumigatus. Appl Environ Microbiol 71:15311538 http://dx.doi.org/10.1128/AEM.71.3.1531-1538.2005.

14. Reese AJ, Yoneda A, Breger JA, Beauvais A, Liu H, Griffith CL, Bose I, Kim MJ, Skau C, Yang S, Sefko JA, Osumi M, Latge JP, Mylonakis E, Doering TL. 2007. Loss of cell wall $\alpha(1-3)$ glucan affects Cryptococcus neoformans from ultrastructure to virulence. Mol Microbiol 63:13851398 http://dx.doi.org/10.1111/j.1365-2958.2006.05551.x.

15. Klutts JS, Doering TL. 2008. Cryptococcal xylosyltransferase 1 (Cxt1p) from Cryptococcus neoformans plays a direct role in the synthesis of capsule polysaccharides. J Biol Chem 283:14327-14334 http://dx.doi .org/10.1074/jbc.M708927200.

16. Moyrand F, Fontaine T, Janbon G. 2007. Systematic capsule gene disruption reveals the central role of galactose metabolism on Cryptococcus neoformans virulence. Mol Microbiol 64:771-781 http://dx.doi .org/10.1111/j.1365-2958.2007.05695.x.

17. Yoneda A, Doering TL. 2006. A eukaryotic capsular polysaccharide is synthesized intracellularly and secreted via exocytosis. Mol Biol Cell 17:5131-5140 http://dx.doi.org/10.1091/mbc.E06-08-0701.

18. Wessels JGH. 1996. Hydrophobins: proteins that change the nature of the fungal surface. Adv Microb Physiol 38:1-45 http://dx.doi.org/10.1016 /S0065-2911(08)60154-X.

19. Dague E, Alsteens D, Latgé JP, Dufrêne YF. 2008. High-resolution cell surface dynamics of germinating Aspergillus fumigatus conidia. Biophys J 94:656-660 http://dx.doi.org/10.1529/biophysj.107.116491.

20. Paris S, Debeaupuis JP, Crameri R, Carey M, Charlès F, Prévost MC, Schmitt C, Philippe B, Latgé JP. 2003. Conidial hydrophobins of Aspergillus fumigatus. Appl Environ Microbiol 69:1581-1588 http://dx.doi .org/10.1128/AEM.69.3.1581-1588.2003.

21. Aimanianda V, Bayry J, Bozza S, Kniemeyer O, Perruccio K, Elluru SR, Clavaud C, Paris S, Brakhage AA, Kaveri SV, Romani L, Latgé JP. 2009. Surface hydrophobin prevents immune recognition of airborne fungal spores. Nature 460:1117-1121 http://dx.doi.org/10.1038/nature08264. 22. Fontaine T, Simenel C, Dubreucq G, Adam O, Delepierre M, Lemoine J, Vorgias CE, Diaquin M, Latgé JP. 2000. Molecular organization of the alkali-insoluble fraction of Aspergillus fumigatus cell wall. J Biol Chem 275:27594-27607.

23. Iorio E, Torosantucci A, Bromuro C, Chiani P, Ferretti A, Giannini M, Cassone A, Podo F. 2008. Candida albicans cell wall comprises a branched

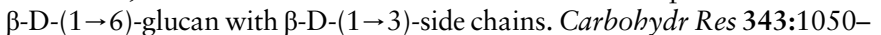
1061 http://dx.doi.org/10.1016/j.carres.2008.02.020.

24. Klis FM, de Groot P, Hellingwerf K. 2001. Molecular organization of the cell wall of Candida albicans. Med Mycol 39(Suppl 1):1-8 http://dx .doi.org/10.1080/mmy.39.1.1.8-0.

25. Bonhomme J, d'Enfert C. 2013. Candida albicans biofilms: building a heterogeneous, drug-tolerant environment. Curr Opin Microbiol 16:398403 http://dx.doi.org/10.1016/j.mib.2013.03.007.

26. Zarnowski R, Westler WM, Lacmbouh GA, Marita JM, Bothe JR, Bernhardt J, Lounes-Hadj Sahraoui A, Fontaine J, Sanchez H, Hatfield RD, Ntambi JM, Nett JE, Mitchell AP, Andes DR. 2014. Novel entries in a fungal biofilm matrix encyclopedia. MBio 5:e01333-e14 http://dx.doi.org /10.1128/mBio.01333-14.

27. Martinez LR, Casadevall A. 2007. Cryptococcus neoformans biofilm formation depends on surface support and carbon source and reduces fungal cell susceptibility to heat, cold, and UV light. Appl Environ Microbiol 73:4592-4601 http://dx.doi.org/10.1128/AEM.02506-06.

28. Cushion MT, Collins MS, Linke MJ. 2009. Biofilm formation by Pneumocystis spp. Eukaryot Cell 8:197-206 http://dx.doi.org/10.1128 /EC.00202-08.

29. Nett J, Lincoln L, Marchillo K, Massey R, Holoyda K, Hoff B, VanHandel M, Andes D. 2007. Putative role of $\beta-1,3$ glucans in Candida albicans biofilm resistance. Antimicrob Agents Chemother 51:510-520 http://dx.doi.org/10.1128/AAC.01056-06.

30. Rajendran R, Sherry L, Lappin DF, Nile CJ, Smith K, Williams C, Munro CA, Ramage G. 2014. Extracellular DNA release confers heterogeneity in Candida albicans biofilm formation. BMC Microbiol 14:303306 http://dx.doi.org/10.1186/s12866-014-0303-6.

31. Al-Fattani MA, Douglas LJ. 2006. Biofilm matrix of Candida albicans and Candida tropicalis: chemical composition and role in drug resistance. J Med Microbiol 55:999-1008 http://dx.doi.org/10.1099/jmm $.0 .46569-0$.

32. Beauvais A, Schmidt C, Guadagnini S, Roux P, Perret E, Henry C, Paris S, Mallet A, Prévost MC, Latgé JP. 2007. An extracellular matrix glues together the aerial-grown hyphae of Aspergillus fumigatus. Cell Microbiol 9:1588-1600 http://dx.doi.org/10.1111/j.1462-5822.2007.00895.x.

33. Cabib E, Roh DH, Schmidt M, Crotti LB, Varma A. 2001. The yeast cell wall and septum as paradigms of cell growth and morphogenesis. J Biol Chem 276:19679-19682 http://dx.doi.org/10.1074/jbc.R000031200.

34. Munro CA, Gow NAR. 2001. Chitin synthesis in human pathogenic fungi. Med Mycol 39(Suppl 1):41-53 http://dx.doi.org/10.1080/mmy.39 .1.41.53.

35. Roncero C. 2002. The genetic complexity of chitin synthesis in fungi. Curr Genet 41:367-378 http://dx.doi.org/10.1007/s00294-002-0318-7.

36. Bowen AR, Chen-Wu JL, Momany M, Young R, Szaniszlo PJ, Robbins PW. 1992. Classification of fungal chitin synthases. Proc Natl Acad Sci USA 89:519-523 http://dx.doi.org/10.1073/pnas.89.2.519.

37. Lenardon MD, Whitton RK, Munro CA, Marshall D, Gow NA. 2007. Individual chitin synthase enzymes synthesize microfibrils of differing structure at specific locations in the Candida albicans cell wall. Mol Microbiol 66:1164-1173 http://dx.doi.org/10.1111/j.1365-2958.2007 $.05990 . \mathrm{x}$.

38. Morozov AA, Likhoshway YV. 2016. Evolutionary history of the chitin synthases of eukaryotes. Glycobiology 26:635-639 http://dx.doi .org/10.1093/glycob/cww018.

39. Fernandes C, Gow NAR, Gonçalves T. 2016. The importance of subclasses of chitin synthase enzymes with myosin-like domains for the fitness of fungi. Fungal Biol Rev 30:1-14 http://dx.doi.org/10.1016/j.fbr .2016 .03 .002 . 
40. Schorr M, Then A, Tahirovic S, Hug N, Mayinger P. 2001. The phosphoinositide phosphatase Sac1p controls trafficking of the yeast Chs3p chitin synthase. Curr Biol 11:1421-1426 http://dx.doi.org/10.1016 IS0960-9822(01)00449-3.

41. Valdivia RH, Schekman R. 2003. The yeasts Rho1p and Pkc1p regulate the transport of chitin synthase III (Chs3p) from internal stores to the plasma membrane. Proc Natl Acad Sci USA 100:10287-10292 http://dx .doi.org/10.1073/pnas.1834246100.

42. Lenardon MD, Munro CA, Gow NAR. 2010. Chitin synthesis and fungal pathogenesis. Curr Opin Microbiol 13:416-423 http://dx.doi.org /10.1016/j.mib.2010.05.002.

43. Munro CA, Winter K, Buchan A, Henry K, Becker JM, Brown AJ, Bulawa CE, Gow NA. 2001. Chs1 of Candida albicans is an essential chitin synthase required for synthesis of the septum and for cell integrity. Mol Microbiol 39:1414-1426 http://dx.doi.org/10.1046/j.1365-2958 .2001.02347.x.

44. Steinberg G. 2011. Motors in fungal morphogenesis: cooperation versus competition. Curr Opin Microbiol 14:660-667 http://dx.doi.org 110.1016/j.mib.2011.09.013.

45. Schuster M, Martin-Urdiroz M, Higuchi Y, Hacker C, Kilaru S, Gurr SJ, Steinberg G. 2016. Co-delivery of cell-wall-forming enzymes in the same vesicle for coordinated fungal cell wall formation. Nat Microbiol 1:16149 http://dx.doi.org/10.1038/nmicrobiol.2016.149.

46. Treitschke S, Doehlemann G, Schuster M, Steinberg G. 2010. The myosin motor domain of fungal chitin synthase $\mathrm{V}$ is dispensable for vesicle motility but required for virulence of the maize pathogen Ustilago maydis. Plant Cell 22:2476-2494 http://dx.doi.org/10.1105 ttpc.110.075028.

47. Schuster M, Treitschke S, Kilaru S, Molloy J, Harmer NJ, Steinberg G. 2012. Myosin-5, kinesin-1 and myosin-17 cooperate in secretion of fungal chitin synthase. EMBO J 31:214-227 http://dx.doi.org/10.1038/emboj .2011.361.

48. Douglas CM. 2001. Fungal $\beta(1,3)-D$-glucan synthesis. Med Mycol 39 (Suppl 1):55-66 http://dx.doi.org/10.1080/mmy.39.1.55.66.

49. Douglas CM, D’Ippolito JA, Shei GJ, Meinz M, Onishi J, Marrinan JA, Li W, Abruzzo GK, Flattery A, Bartizal K, Mitchell A, Kurtz MB. 1997. Identification of the FKS1 gene of Candida albicans as the essential target of 1,3-beta-D-glucan synthase inhibitors. Antimicrob Agents Chemother 41:2471-2479.

50. Piotrowski JS, Okada H, Lu F, Li SC, Hinchman L, Ranjan A, Smith DL, Higbee AJ, Ulbrich A, Coon JJ, Deshpande R, Bukhman YV, Mcllwain S, Ong IM, Myers CL, Boone C, Landick R, Ralph J, Kabbage M, Ohya Y. 2015. Plant-derived antifungal agent poacic acid targets 及-1,3-glucan. Proc Natl Acad Sci USA 112:E1490-E1497. http://dx.doi .org/10.1073/pnas.1410400112.

51. Park S, Kelly R, Kahn JN, Robles J, Hsu MJ, Register E, Li W, Vyas V, Fan H, Abruzzo G, Flattery A, Gill C, Chrebet G, Parent SA, Kurtz M, Teppler H, Douglas CM, Perlin DS. 2005. Specific substitutions in the echinocandin target Fks1p account for reduced susceptibility of rare laboratory and clinical Candida sp. isolates. Antimicrob Agents Chemother 49:3264-3273 http://dx.doi.org/10.1128/AAC.49.8.3264-3273.2005.

52. Mouyna I, Henry C, Doering TL, Latgé JP. 2004. Gene silencing with RNA interference in the human pathogenic fungus Aspergillus fumigatus. FEMS Microbiol Lett 237:317-324.

53. Thompson JR, Douglas CM, Li W, Jue CK, Pramanik B, Yuan X, Rude TH, Toffaletti DL, Perfect JR, Kurtz M. 1999. A glucan synthase FKS1 homolog in Cryptococcus neoformans is single copy and encodes an essential function. J Bacteriol 181:444-453.

54. Cutler JE. 2001. N-glycosylation of yeast, with emphasis on Candida albicans. Med Mycol 39(Suppl 1):75-86 http://dx.doi.org/10.1080/mmy 39.1.75.86.

55. Hall RA, Gow NAR. 2013. Mannosylation in Candida albicans: role in cell wall function and immune recognition. Mol Microbiol 90:11471161 http://dx.doi.org/10.1111/mmi.12426.
56. Ma L, Chen Z, Huang DW, Kutty G, Ishihara M, Wang H, Abouelleil A, Bishop L, Davey E, Dend R, Dend X, Fan L, Fantoni G, Fitzgerald M, Gogineni E, Goldberg JM, Handley G, Hu X, Huber C, Jiao X, Jones K, Levin JZ, Liu Y, MacDonald P, Melnikov A, Raley C, Brad MS, Sherman BT, Song X, Sykes S, Tran B, Walsh L, Xia Y, Yang J, Young S, Zeng Q, Zheng X, Lempick RA, Cuomo CA, Kovacs JA. 2015. Mechanisms of adaptation to life exclusively in mammalian hosts by Pneumocystis. Nat Commun 7:10740. doi:10.1038/ncomms10740.

57. Henry C, Fontaine T, Heddergott C, Robinet P, Aimanianda V, Beau R, Beauvais A, Mouyna I, Prevost M-C, Zhao Y, Perlin D, Latge JP. 2016. Biosynthesis of cell wall mannan in the conidium and the mycelium of Aspergillus fumigatus. Cell Microbiol 18:1881-1891.

58. Reese AJ, Doering TL. 2003. Cell wall $\alpha-1,3$-glucan is required to anchor the Cryptococcus neoformans capsule. Mol Microbiol 50:14011409 http://dx.doi.org/10.1046/j.1365-2958.2003.03780.x.

59. Fu C, Tanaka A, Free SJ. 2014. Neurospora crassa 1,3- $\alpha$-glucan synthase, AGS-1, is required for cell wall biosynthesis during macroconidia development. Microbiology 160:1618-1627 http://dx.doi.org /10.1099/mic.0.080002-0.

60. Beauvais A, Bozza S, Kniemeyer O, Formosa C, Balloy V, Henry C, Roberson RW, Dague E, Chignard M, Brakhage AA, Romani L, Latgé JP. 2013. Deletion of the $\alpha-(1,3)$-glucan synthase genes induces a restructuring of the conidial cell wall responsible for the avirulence of Aspergillus fumigatus. PLoS Pathog 9:e1003716 http://dx.doi.org/10.1371/journal .ppat.1003716.

61. Aimanianda V, Clavaud C, Simenel C, Fontaine T, Delepierre M, Latgé JP. 2009. Cell wall $\beta$-(1,6)-glucan of Saccharomyces cerevisiae: structural characterization and in situ synthesis. J Biol Chem 284:1340113412 http://dx.doi.org/10.1074/jbc.M807667200.

62. Shahinian S, Bussey H. 2000. $\beta$-1,6-glucan synthesis in Saccharomyces cerevisiae. Mol Microbiol 35:477-489 http://dx.doi.org/10.1046/j.1365 -2958.2000.01713.x.

63. Herrero AB, Magnelli P, Mansour MK, Levitz SM, Bussey H, Abeijon C. 2004. KRE5 gene null mutant strains of Candida albicans are avirulent and have altered cell wall composition and hypha formation properties. Eukaryot Cell 3:1423-1432 http://dx.doi.org/10.1128/EC.3.6.1423-1432.2004.

64. Latge JP. 2009. Galactofuranose containing molecules in Aspergillus fumigatus. Med Mycol 47(Suppl 1):S104-S109 http://dx.doi.org/10.1080 /13693780802258832.

65. Lee MJ, Gravelat FN, Cerone RP, Baptista SD, Campoli PV, Choe SI, Kravtsov I, Vinogradov E, Creuzenet C, Liu H, Berghuis AM, Latgé JP, Filler SG, Fontaine T, Sheppard DC. 2014. Overlapping and distinct roles of Aspergillus fumigatus UDP-glucose 4-epimerases in galactose metabolism and the synthesis of galactose-containing cell wall polysaccharides. J Biol Chem 289:1243-1256 http://dx.doi.org/10.1074/jbc.M113.522516.

66. Gilbert NM, Donlin MJ, Gerik KJ, Specht CA, Djordjevic JT, Wilson CF, Sorrell TC, Lodge JK. 2010. KRE genes are required for $\beta-1,6$-glucan synthesis, maintenance of capsule architecture and cell wall protein anchoring in Cryptococcus neoformans. Mol Microbiol 76:517-534 http://dx.doi.org/10.1111/j.1365-2958.2010.07119.x.

67. Lee MJ, Geller AM, Bamford NC, Liu H, Gravelat FN, Snarr BD, Le Mauff F, Chabot J, Ralph B, Ostapska H, Lehoux M, Cerone RP, Baptista SD, Vinogradov E, Stajich JE, Filler SG, Howell PL, Sheppard DC. 2016. Deacetylation of fungal exopolysaccharide mediates adhesion and biofilm formation. MBio 7:e00252-e16 http://dx.doi.org/10.1128/mBio.00252-16. 68. Glasgow JE, Reissig JL. 1974. Interaction of galactosaminoglycan with Neurospora conidia. J Bacteriol 120:759-766.

69. Gravelat FN, Beauvais A, Liu H, Lee MJ, Snarr BD, Chen D, Xu W, Kravtsov I, Hoareau CMQ, Vanier G, Urb M, Campoli P, Al Abdallah Q, Lehoux M, Chabot JC, Ouimet M-C, Baptista SD, Fritz JHJ, Nierman WC, Latgé J-P, Mitchell AP, Filler SG, Fontaine T, Sheppard DC. 2013. Aspergillus galactosaminogalactan mediates adherence to host constituents and conceals hyphal $\beta$-glucan from the immune system. PLoS Pathog 9:e1003575 http://dx.doi.org/10.1371/journal.ppat.1003575. 
70. Gresnigt MS, Bozza S, Becker KL, Joosten LAB, Abdollahi-Roodsaz S, van der Berg WB, Dinarello CA, Netea MG, Fontaine T, De Luca A, Moretti S, Romani L, Latge J-P, van de Veerdonk FL. 2014. A polysaccharide virulence factor from Aspergillus fumigatus elicits anti-inflammatory effects through induction of interleukin-1 receptor antagonist. PLOS Pathog 10:e1003936 http://dx.doi.org/10.1371/journal.ppat.1003936.

71. Nosanchuk JD, Stark RE, Casadevall A. 2015. Fungal melanin: what do we know about structure? Front Microbiol 6:1463 http://dx.doi.org 110.3389/fmicb.2015.01463.

72. Nosanchuk JD, Casadevall A. 2006. Impact of melanin on microbial virulence and clinical resistance to antimicrobial compounds. Antimicrob Agents Chemother 50:3519-3528 http://dx.doi.org/10.1128 IAAC.00545-06.

73. Walker CA, Gómez BL, Mora-Montes HM, Mackenzie KS, Munro CA, Brown AJP, Gow NAR, Kibbler CC, Odds FC. 2010. Melanin externalization in Candida albicans depends on cell wall chitin structures. Eukaryot Cell 9:1329-1342 http://dx.doi.org/10.1128/EC.00051-10.

74. Eisenman HC, Nosanchuk JD, Webber JB, Emerson RJ, Camesano TA, Casadevall A. 2005. Microstructure of cell wall-associated melanin in the human pathogenic fungus Cryptococcus neoformans. Biochemistry 44:3683-3693 http://dx.doi.org/10.1021/bi047731m.

75. Walton FJ, Idnurm A, Heitman J. 2005. Novel gene functions required for melanization of the human pathogen Cryptococcus neoformans. Mol Microbiol 57:1381-1396 http://dx.doi.org/10.1111/j.1365-2958.2005 $.04779 . x$.

76. Tsai HF, Chang YC, Washburn RG, Wheeler MH, Kwon-Chung KJ. 1998. The developmentally regulated alb1 gene of Aspergillus fumigatus: its role in modulation of conidial morphology and virulence. J Bacteriol 180:3031-3038.

77. Langfelder K, Streibel M, Jahn B, Haase G, Brakhage AA. 2003. Biosynthesis of fungal melanins and their importance for human pathogenic fungi. Fungal Genet Biol 38:143-158 http://dx.doi.org/10.1016 /S1087-1845(02)00526-1.

78. Paolo WF Jr, Dadachova E, Mandal P, Casadevall A, Szanislo PJ, Nosanchuk JD. 2006. Effects of disrupting the polyketide synthase gene WdPKS1 in Wangiella (Exophiala) dermatitidis on melanin production and resistance to killing by antifungal compounds, enzymatic degradation, and extremes in temperature. BMC Microbiol 6:55. doi:10.1186/1471 $\underline{-2180-6-55}$.

79. Butler G, Rasmussen MD, Lin MF, Santos M, Sakthikumar S, Munro CA, Rheinbay E, Grabherr M, Agrafioti I, Arnaud MB, Bates S, Berman J, Brown AJP, Brunke S, Constanzo MC, Fitzpatrick DA, Forche A, de Groot PWJ, Harris D, Hoyer L, Hube B, Klis FM, Kodira C, Lennard N, Logue ME, Martin R, Neiman AM, Nikolaou E, Quail M, Quinn J, Reedy JL, Schmitzberger FF, Sherlock G, Shah P, Silverstein K, Skrypek MS, Soll DR, Staggs S, Stumpf MPH, Sudbery PE, Thyagarajan S, Zeng Q, Berriman M, Heitman J, Lorenz MC, Gow NAR, Birren BW, Kellis M, Cuomo CA. 2009. Evolution of pathogenicity and sexual reproduction in eight Candida genomes. Nature 459:657-662 http://dx.doi.org/10.1038 Inature08064.

80. de Groot PW, Hellingwerf KJ, Klis FM. 2003. Genome-wide identification of fungal GPI proteins. Yeast 20:781-796 http://dx.doi.org/10.1002 /yea.1007.

81. Eisenhaber B, Schneider G, Wildpaner M, Eisenhaber F. 2004. A sensitive predictor for potential GPI lipid modification sites in fungal protein sequences and its application to genome-wide studies for Aspergillus nidulans, Candida albicans, Neurospora crassa, Saccharomyces cerevisiae and Schizosaccharomyces pombe. J Mol Biol 337:243-253 http://dx.doi.org/10.1016/j.jmb.2004.01.025.

82. de Groot PW, de Boer AD, Cunningham J, Dekker HL, de Jong L, Hellingwerf KJ, de Koster C, Klis FM. 2004. Proteomic analysis of Candida albicans cell walls reveals covalently bound carbohydrate-active enzymes and adhesins. Eukaryot Cell 3:955-965 http://dx.doi.org/10.1128 /EC.3.4.955-965.2004.
83. MacCallum DM, Castillo L, Nather K, Munro CA, Brown AJP, Gow NAR, Odds FC. 2009. Property differences among the four major Candida albicans strain clades. Eukaryot Cell 8:373-387 http://dx.doi .org/10.1128/EC.00387-08.

84. Castillo L, Calvo E, Martínez AI, Ruiz-Herrera J, Valentín E, Lopez JA, Sentandreu R. 2008. A study of the Candida albicans cell wall proteome. Proteomics 8:3871-3881 http://dx.doi.org/10.1002/pmic .200800110 .

85. Yin QY, de Groot PW, de Koster CG, Klis FM. 2008. Mass spectrometry-based proteomics of fungal wall glycoproteins. Trends Microbiol 16:20-26 http://dx.doi.org/10.1016/j.tim.2007.10.011.

86. Chaffin WL. 2008. Candida albicans cell wall proteins. Microbiol Mol Biol Rev 72:495-544 http://dx.doi.org/10.1128/MMBR.00032-07.

87. Ene IV, Heilmann CJ, Sorgo AG, Walker LA, de Koster CG, Munro CA, Klis FM, Brown AJP. 2012. Carbon source-induced reprogramming of the cell wall proteome and secretome modulates the adherence and drug resistance of the fungal pathogen Candida albicans. Proteomics 12:31643179 http://dx.doi.org/10.1002/pmic.201200228.

88. Sorgo AG, Brul S, de Koster CG, de Koning LJ, Klis FM. 2013. Iron restriction-induced adaptations in the wall proteome of Candida albicans. Microbiology 159:1673-1682 http://dx.doi.org/10.1099/mic.0 $.065599-0$.

89. Pitarch A, Jiménez A, Nombela C, Gil C. 2006. Decoding serological response to Candida cell wall immunome into novel diagnostic, prognostic, and therapeutic candidates for systemic candidiasis by proteomic and bioinformatic analyses. Mol Cell Proteomics 5:79-96 http://dx.doi .org/10.1074/mcp.M500243-MCP200.

90. Sohn K, Schwenk J, Urban C, Lechner J, Schweikert M, Rupp S. 2006. Getting in touch with Candida albicans: the cell wall of a fungal pathogen. Curr Drug Targets 7:505-512 http://dx.doi.org/10.2174/13894500677 6359395.

91. Klis FM, de Jong M, Brul S, de Groot PW. 2007. Extraction of cell surface-associated proteins from living yeast cells. Yeast 24:253-258 http://dx.doi.org/10.1002/yea.1476.

92. Casadevall A, Nosanchuk JD, Williamson P, Rodrigues ML. 2009. Vesicular transport across the fungal cell wall. Trends Microbiol 17:158162 http://dx.doi.org/10.1016/j.tim.2008.12.005.

93. Crowe JD, Sievwright IK, Auld GC, Moore NR, Gow NAR, Booth NA. 2003. Candida albicans binds human plasminogen: identification of eight plasminogen-binding proteins. Mol Microbiol 47:16371651 http://dx.doi.org/10.1046/j.1365-2958.2003.03390.x.

94. Urban C, Xiong X, Sohn K, Schröppel K, Brunner H, Rupp S. 2005. The moonlighting protein Tsa $1 \mathrm{p}$ is implicated in oxidative stress response and in cell wall biogenesis in Candida albicans. Mol Microbiol 57:1318-1341 http://dx.doi.org/10.1111/j.1365-2958.2005.04771.x.

95. Hurtado-Guerrero R, Schüttelkopf AW, Mouyna I, Ibrahim AF, Shepherd S, Fontaine T, Latgé JP, van Aalten DM. 2009. Molecular mechanisms of yeast cell wall glucan remodeling. J Biol Chem 284:84618469 http://dx.doi.org/10.1074/jbc.M807990200.

96. Mouyna I, Hartl L, Latgé JP. 2013. $\beta-1,3-G l u c a n$ modifying enzymes in Aspergillus fumigatis. Front Microbiol 4:81. http://dx.doi.org/10.3389 /fmicb.2013.00081.

97. Cabib E, Blanco N, Grau C, Rodríguez-Peña JM, Arroyo J. 2007. Crh1p and Crh2p are required for the cross-linking of chitin to $\beta(1-6)$ glucan in the Saccharomyces cerevisiae cell wall. Mol Microbiol 63:921935 http://dx.doi.org/10.1111/j.1365-2958.2006.05565.x.

98. Cabib E, Farkas V, Kosík O, Blanco N, Arroyo J, McPhie P. 2008. Assembly of the yeast cell wall. Crh1p and Crh2p act as transglycosylases in vivo and in vitro. J Biol Chem 283:29859-29872 http://dx.doi.org /10.1074/jbc.M804274200.

99. Arroyo J, Farkaš V, Sanz AB, Cabib E. 2016. Strengthening the fungal cell wall through chitin-glucan cross-links: effects on morphogenesis and cell integrity. Cell Microbiol 18:1239-1250 http://dx.doi.org/10.1111 /cmi.12615. 
Gow et al.

100. Cabib E, Silverman SJ, Shaw JA. 1992. Chitinase and chitin synthase 1: counterbalancing activities in cell separation of Saccharomyces cerevisiae. J Gen Microbiol 138:97-102 http://dx.doi.org/10.1099/00221287 -138-1-97.

101. Martín-Cuadrado AB, Dueñas E, Sipiczki M, Vázquez de Aldana CR, del Rey F. 2003. The endo-beta-1,3-glucanase eng1p is required for dissolution of the primary septum during cell separation in Schizosaccharomyces pombe. J Cell Sci 116:1689-1698 http://dx.doi.org/10.1242 jics.00377.

102. Wessels JGH. 1993. Wall growth, protein excretion and morphogenesis in fungi. New Phytol 123:397-413 http://dx.doi.org/10.1111 j.1469-8137.1993.tb03751.x.

103. Seidl V. 2008. Chitinases of filamentous fungi: a large group of diverse proteins with multiple physiological functions. Fungal Biol Rev 22:36-42 http://dx.doi.org/10.1016/j.fbr.2008.03.002.

104. Selvaggini S, Munro CA, Paschoud S, Sanglard D, Gow NAR. 2004. Independent regulation of chitin synthase and chitinase activity in Candida albicans and Saccharomyces cerevisiae. Microbiology 150:921928 http://dx.doi.org/10.1099/mic.0.26661-0.

105. Baker LG, Specht CA, Lodge JK. 2011. Cell wall chitosan is necessary for virulence in the opportunistic pathogen Cryptococcus neoformans. Eukaryot Cell 10:1264-1268 http://dx.doi.org/10.1128/EC .05138-11.

106. Gagnon-Arsenault I, Parisé L, Tremblay J, Bourbonnais Y. 2008. Activation mechanism, functional role and shedding of glycosylphosphatidylinositol-anchored Yps1p at the Saccharomyces cerevisiae cell surface. Mol Microbiol 69:982-993 http://dx.doi.org/10.1111/j.1365-2958.2008 .06339.x.

107. Albrecht A, Felk A, Pichova I, Naglik JR, Schaller M, de Groot P, Maccallum D, Odds FC, Schäfer W, Klis F, Monod M, Hube B. 2006. Glycosylphosphatidylinositol-anchored proteases of Candida albicans target proteins necessary for both cellular processes and host-pathogen interactions. J Biol Chem 281:688-694 http://dx.doi.org/10.1074/jbc M509297200.

108. Kaur R, Ma B, Cormack BP. 2007. A family of glycosylphosphatidylinositol-linked aspartyl proteases is required for virulence of Candida glabrata. Proc Natl Acad Sci USA 104:7628-7633 http://dx.doi .org/10.1073/pnas.0611195104.

109. Sundstrom P. 2002. Adhesion in Candida spp. Cell Microbiol 4:461469 http://dx.doi.org/10.1046/j.1462-5822.2002.00206.x.

110. Hoyer LL, Green CB, Oh SH, Zhao X. 2008. Discovering the secrets of the Candida albicans agglutinin-like sequence (ALS) gene family-a sticky pursuit. Med Mycol 46:1-15.

111. De Las Peñas A, Pan SJ, Castaño I, Alder J, Cregg R, Cormack BP. 2003. Virulence-related surface glycoproteins in the yeast pathogen Candida glabrata are encoded in subtelomeric clusters and subject to RAP1- and SIR-dependent transcriptional silencing. Genes Dev 17:22452258 http://dx.doi.org/10.1101/gad.1121003.

112. de Groot PW, Kraneveld EA, Yin QY, Dekker HL, Gross U, Crielaard W, de Koster CG, Bader O, Klis FM, Weig M. 2008. The cell wall of the human pathogen Candida glabrata: differential incorporation of novel adhesin-like wall proteins. Eukaryot Cell 7:1951-1964 http://dx doi.org/10.1128/EC.00284-08.

113. Frieman MB, McCaffery JM, Cormack BP. 2002. Modular domain structure in the Candida glabrata adhesin Epa1p, a $\beta 1,6$ glucan-crosslinked cell wall protein. Mol Microbiol 46:479-492 http://dx.doi.org 10.1046/j.1365-2958.2002.03166.x.

114. Li F, Palecek SP. 2008. Distinct domains of the Candida albicans adhesin Eap1p mediate cell-cell and cell-substrate interactions. Microbiology 154:1193-1203 http://dx.doi.org/10.1099/mic.0.2007/013789-0.

115. Sheppard DC, Yeaman MR, Welch WH, Phan QT, Fu Y, Ibrahim AS, Filler SG, Zhang M, Waring AJ, Edwards JE Jr. 2004. Functional and structural diversity in the Als protein family of Candida albicans. J Biol Chem 279:30480-30489 http://dx.doi.org/10.1074/jbc.M401929200.
116. Zupancic ML, Frieman M, Smith D, Alvarez RA, Cummings RD, Cormack BP. 2008. Glycan microarray analysis of Candida glabrata adhesin ligand specificity. Mol Microbiol 68:547-559 http://dx.doi.org /10.1111/j.1365-2958.2008.06184.x.

117. Staab JF, Bradway SD, Fidel PL, Sundstrom P. 1999. Adhesive and mammalian transglutaminase substrate properties of Candida albicans Hwp1. Science 283:1535-1538 http://dx.doi.org/10.1126/science.283 .5407 .1535 .

118. Nobile CJ, Schneider HA, Nett JE, Sheppard DC, Filler SG, Andes DR, Mitchell AP. 2008. Complementary adhesin function in C. albicans biofilm formation. Curr Biol 18:1017-1024 http://dx.doi.org/10.1016 lj.cub.2008.06.034.

119. Li F, Svarovsky MJ, Karlsson AJ, Wagner JP, Marchillo K, Oshel P, Andes D, Palecek SP. 2007. Eap1p, an adhesin that mediates Candida albicans biofilm formation in vitro and in vivo. Eukaryot Cell 6:931-939 http://dx.doi.org/10.1128/EC.00049-07.

120. Firon A, Aubert S, Iraqui I, Guadagnini S, Goyard S, Prévost MC, Janbon G, d'Enfert C. 2007. The SUN41 and SUN42 genes are essential for cell separation in Candida albicans. Mol Microbiol 66:1256-1275 http://dx.doi.org/10.1111/j.1365-2958.2007.06011.x.

121. Hiller E, Heine S, Brunner H, Rupp S. 2007. Candida albicans Sun41p, a putative glycosidase, is involved in morphogenesis, cell wall biogenesis, and biofilm formation. Eukaryot Cell 6:2056-2065 http://dx .doi.org/10.1128/EC.00285-07.

122. Norice CT, Smith FJ Jr, Solis N, Filler SG, Mitchell AP. 2007. Requirement for Candida albicans Sun 41 in biofilm formation and virulence. Eukaryot Cell 6:2046-2055 http://dx.doi.org/10.1128/EC.00314-07.

123. Pérez A, Pedrós B, Murgui A, Casanova M, López-Ribot JL, Martínez JP. 2006. Biofilm formation by Candida albicans mutants for genes coding fungal proteins exhibiting the eight-cysteine-containing CFEM domain. FEMS Yeast Res 6:1074-1084 http://dx.doi.org/10.1111 /j.1567-1364.2006.00131.x.

124. Wösten HA, de Vocht ML. 2000. Hydrophobins, the fungal coat unravelled. Biochim Biophys Acta 1469:79-86 http://dx.doi.org/10.1016 /S0304-4157(00)00002-2.

125. Albuquerque P, Kyaw CM, Saldanha RR, Brigido MM, Felipe MSS, Silva-Pereira I. 2004. Pbhyd1 and Pbhyd2: two mycelium-specific hydrophobin genes from the dimorphic fungus Paracoccidioides brasiliensis. Fungal Genet Biol 41:510-520 http://dx.doi.org/10.1016/j.fgb.2004.01 .001

126. Cho EM, Kirkland BH, Holder DJ, Keyhani NO. 2007. Phage display cDNA cloning and expression analysis of hydrophobins from the entomopathogenic fungus Beauveria (Cordyceps) bassiana. Microbiology 153:3438-3447 http://dx.doi.org/10.1099/mic.0.2007/008532-0.

127. Kim S, Ahn IP, Rho HS, Lee YH. 2005. MHP1, a Magnaporthe grisea hydrophobin gene, is required for fungal development and plant colonization. Mol Microbiol 57:1224-1237 http://dx.doi.org/10.1111 /j.1365-2958.2005.04750.x.

128. Müller O, Schreier PH, Uhrig JF. 2008. Identification and characterization of secreted and pathogenesis-related proteins in Ustilago maydis. Mol Genet Genomics 279:27-39 http://dx.doi.org/10.1007/s00438 -007-0291-4.

129. Levin DE. 2005. Cell wall integrity signaling in Saccharomyces cerevisiae. Microbiol Mol Biol Rev 69:262-291 http://dx.doi.org/10.1128 /MMBR.69.2.262-291.2005.

130. Rispail N, Soanes DM, Ant C, Czajkowski R, Grünler A, Huguet R, Perez-Nadales E, Poli A, Sartorel E, Valiante V, Yang M, Beffa R, Brakhage AA, Gow NAR, Kahmann R, Lebrun M-H, Lenasi H, Perez-Martin J, Talbot NJ, Wendland J, Di Pietro A. 2009. Comparative genomics of MAP kinase and calcium-calcineurin signalling components in plant and human pathogenic fungi. Fungal Genet Biol 46:287-298 http://dx.doi.org/10.1016 /j.fgb.2009.01.002.

131. Munro CA, Selvaggini S, de Bruijn I, Walker L, Lenardon MD, Gerssen B, Milne S, Brown AJ, Gow NAR. 2007. The PKC, HOG and 
$\mathrm{Ca}^{2+}$ signalling pathways co-ordinately regulate chitin synthesis in Candida albicans. Mol Microbiol 63:1399-1413 http://dx.doi.org/10.1111 /j.1365-2958.2007.05588.x.

132. Popolo L, Gualtieri T, Ragni E. 2001. The yeast cell-wall salvage pathway. Med Mycol 39(Suppl 1):111-121 http://dx.doi.org/10.1080 /mmy.39.1.111.121.

133. García R, Bermejo C, Grau C, Pérez R, Rodríguez-Peña JM, Francois J, Nombela C, Arroyo J. 2004. The global transcriptional response to transient cell wall damage in Saccharomyces cerevisiae and its regulation by the cell integrity signaling pathway. J Biol Chem 279:15183-15195 http://dx.doi.org/10.1074/jbc.M312954200.

134. Bruno VM, Kalachikov S, Subaran R, Nobile CJ, Kyratsous C, Mitchell AP. 2006. Control of the C. albicans cell wall damage response by transcriptional regulator Cas5. PLoS Pathog 2:e21 http://dx.doi.org /10.1371/journal.ppat.0020021.

135. Rauceo JM, Blankenship JR, Fanning S, Hamaker JJ, Deneault J-S, Smith FJ, Nantel A, Mitchell AP. 2008. Regulation of the Candida albicans cell wall damage response by transcription factor Sko1 and PAS kinase Psk1. Mol Biol Cell 19:2741-2751 http://dx.doi.org/10.1091/mbc .E08-02-0191.

136. Karababa M, Valentino E, Pardini G, Coste AT, Bille J, Sanglard D. 2006. CRZ1, a target of the calcineurin pathway in Candida albicans. Mol Microbiol 59:1429-1451 http://dx.doi.org/10.1111/j.1365-2958.2005 .05037.x.

137. Reinoso-Martín C, Schüller C, Schuetzer-Muehlbauer M, Kuchler K. 2003. The yeast protein kinase $C$ cell integrity pathway mediates tolerance to the antifungal drug caspofungin through activation of Slt $2 \mathrm{p}$ mitogenactivated protein kinase signaling. Eukaryot Cell 2:1200-1210 http://dx .doi.org/10.1128/EC.2.6.1200-1210.2003.

138. Walker LA, Munro CA, de Bruijn I, Lenardon MD, McKinnon A, Gow NAR. 2008. Stimulation of chitin synthesis rescues Candida albicans from echinocandins. PLoS Pathog 4:e1000040 http://dx.doi.org/10.1371 ljournal.ppat.1000040.

139. Del Poeta M, Cruz MC, Cardenas ME, Perfect JR, Heitman J. 2000. Synergistic antifungal activities of bafilomycin $\mathrm{A}(1)$, fluconazole, and the pneumocandin MK-0991/caspofungin acetate (L-743,873) with calcineurin inhibitors FK506 and L-685,818 against Cryptococcus neoformans. Antimicrob Agents Chemother 44:739-746 http://dx.doi.org/10.1128 /AAC.44.3.739-746.2000.

140. Steinbach WJ, Cramer RA Jr, Perfect BZ, Henn C, Nielsen K, Heitman J, Perfect JR. 2007. Calcineurin inhibition or mutation enhances cell wall inhibitors against Aspergillus fumigatus. Antimicrob Agents Chemother 51:2979-2981 http://dx.doi.org/10.1128/AAC.01394-06.

141. Wiederhold NP, Kontoyiannis DP, Prince RA, Lewis RE. 2005. Attenuation of the activity of caspofungin at high concentrations against Candida albicans: possible role of cell wall integrity and calcineurin pathways. Antimicrob Agents Chemother 49:5146-5148 http://dx.doi .org/10.1128/AAC.49.12.5146-5148.2005.

142. Walker LA, Lenardon MD, Preechasuth K, Munro CA, Gow NA. 2013. Cell wall stress induces alternative fungal cytokinesis and septation strategies. J Cell Sci 126:2668-2677 http://dx.doi.org/10.1242/jcs .118885 .

143. Weber I, Assmann D, Thines E, Steinberg G. 2006. Polar localizing class $\mathrm{V}$ myosin chitin synthases are essential during early plant infection in the plant pathogenic fungus Ustilago maydis. Plant Cell 18:225-242 http://dx.doi.org/10.1105/tpc.105.037341.

144. DeMarini DJ, Adams AE, Fares H, De Virgilio C, Valle G, Chuang JS, Pringle JR. 1997. A septin-based hierarchy of proteins required for localized deposition of chitin in the Saccharomyces cerevisiae cell wall. J Cell Biol 139:75-93 http://dx.doi.org/10.1083/jcb.139.1.75.

145. Rowbottom L, Munro CA, Gow NAR. 2004. Candida albicans mutants in the BNI4 gene have reduced cell-wall chitin and alterations in morphogenesis. Microbiology 150:3243-3252 http://dx.doi.org/10.1099 Imic.0.27167-0.
146. Kozubowski L, Heitman J. 2010. Septins enforce morphogenetic events during sexual reproduction and contribute to virulence of Cryptococcus neoformans. Mol Microbiol 75:658-675 http://dx.doi.org /10.1111/j.1365-2958.2009.06983.x.

147. Vargas-Muñiz JM, Renshaw H, Richards AD, Lamoth F, Soderblom EJ, Moseley MA, Juvvadi PR, Steinbach WJ. 2015. The Aspergillus fumigatus septins play pleiotropic roles in septation, conidiation, and cell wall stress, but are dispensable for virulence. Fungal Genet Biol 81:41-51 http://dx.doi.org/10.1016/j.fgb.2015.05.014.

148. García I, Jiménez D, Martín V, Durán A, Sánchez Y. 2005. The $\alpha$ glucanase Agn1p is required for cell separation in Schizosaccharomyces pombe. Biol Cell 97:569-576 http://dx.doi.org/10.1042/BC20040096.

149. Sudbery PE. 2008. Regulation of the polarised growth in fungi. Fungal Biol Rev 22:44-55 http://dx.doi.org/10.1016/j.fbr.2008.07.001.

150. Virag A, Harris SD. 2006. The Spitzenkörper: a molecular perspective. Mycol Res 110:4-13 http://dx.doi.org/10.1016/j.mycres.2005.09.005.

151. Machesky LM, Gould KL. 1999. The Arp2/3 complex: a multifunctional actin organizer. Curr Opin Cell Biol 11:117-121 http://dx.doi .org/10.1016/S0955-0674(99)80014-3.

152. Lipschutz JH, Mostov KE. 2002. Exocytosis: the many masters of the exocyst. Curr Biol 12:R212-R214 http://dx.doi.org/10.1016/S0960-9822 (02)00753-4.

153. Irazoqui JE, Lew DJ. 2004. Polarity establishment in yeast. J Cell Sci 117:2169-2171 http://dx.doi.org/10.1242/jcs.00953.

154. Johnson DI. 1999. Cdc42: an essential Rho-type GTPase controlling eukaryotic cell polarity. Microbiol Mol Biol Rev 63:54-105.

155. Steinberg G. 2007. On the move: endosomes in fungal growth and pathogenicity. Nat Rev Microbiol 5:309-316 http://dx.doi.org/10.1038 Inrmicro1618.

156. Domer JE. 1971. Monosaccharide and chitin content of cell walls of Histoplasma capsulatum and Blastomyces dermatitidis. J Bacteriol 107: 870-877.

157. Kanetsuna F, Carbonell LM, Moreno RE, Rodriguez J. 1969. Cell wall composition of the yeast and mycelial forms of Paracoccidioides brasiliensis. J Bacteriol 97:1036-1041.

158. Oliveira-Garcia E, Deising HB. 2016. Attenuation of PAMPtriggered immunity in maize requires down-regulation of the key $\beta-1,6-$ glucan synthesis genes KRE5 and KRE6 in biotrophic hyphae of Colletotrichum graminicola. Plant J 87:355-375 http://dx.doi.org/10.1111/tpi .13205 .

159. Brown AJP, Brown GD, Netea MG, Gow NAR. 2014. Metabolism impacts upon Candida immunogenicity and pathogenicity at multiple levels. Trends Microbiol 22:614-622 http://dx.doi.org/10.1016/j.tim.2014 .07 .001 .

160. Odds FC, Brown AJ, Gow NAR. 2003. Antifungal agents: mechanisms of action. Trends Microbiol 11:272-279 http://dx.doi.org /10.1016/S0966-842X(03)00117-3.

161. Fairlamb AH, Gow NAR, Matthews KR, Waters AP. 2016. Drug resistance in eukaryotic microorganisms. Nat Microbiol 1:16092 http://dx.doi.org/10.1038/nmicrobiol.2016.92.

162. Perlin DS. 2007. Resistance to echinocandin-class antifungal drugs. Drug Resist Updat 10:121-130 http://dx.doi.org/10.1016/j.drup.2007 .04 .002 .

163. Netea MG, Brown GD, Kullberg BJ, Gow NAR. 2008. An integrated model of the recognition of Candida albicans by the innate immune system. Nat Rev Microbiol 6:67-78 http://dx.doi.org/10.1038/nrmicro1815. 164. Reid DM, Gow NAR, Brown GD. 2009. Pattern recognition: recent insights from dectin-1. Curr Opin Immunol 21:30-37 http://dx.doi.org /10.1016/j.coi.2009.01.003.

165. van de Veerdonk FL, Kullberg BJ, van der Meer JW, Gow NAR, Netea MG. 2008. Host-microbe interactions: innate pattern recognition of fungal pathogens. Curr Opin Microbiol 11:305-312 http://dx.doi.org /10.1016/i.mib.2008.06.002. 
166. Lee CG, Da Silva CA, Lee JY, Hartl D, Elias JA. 2008. Chitin regulation of immune responses: an old molecule with new roles. Curr Opin Immunol 20:684-689 http://dx.doi.org/10.1016/j.coi.2008.10.002.

167. Reese TA, Liang HE, Tager AM, Luster AD, Van Rooijen N, Voehringer D, Locksley RM. 2007. Chitin induces accumulation in tissue of innate immune cells associated with allergy. Nature 447:92-96 http://dx.doi.org/10.1038/nature05746.

168. Wagener J, Malireddi SRK, Lenardon MD, Köberle M, Vautier S, MacCallum DM, Biedermann T, Schaller M, Netea MG, Kanneganti T-D, Brown GB, Brown AJP, Gow NAR. 2014. Fungal chitin dampens inflammation through NOD2 and TLR9 activation. PLoS Pathog 10: e1004050. doi:10.1371/journal.ppat.1004050.

169. Becker KL, Aimanianda V, Wang X, Gresnigt MS, Ammerdorffer A, Jacobs CW, Gazendam RP, Joosten LAB, Netea MG, Latgé JP, van de Veerdonk FL. 2016. Aspergillus cell wall chitin induces anti- and proinflammatory cytokines in human PBMCs via the Fc- $\gamma$ ceceptor/Syk/PI3K pathway. MBio 7:e01823-e15 http://dx.doi.org/10.1128/mBio.01823-15.

170. Da Silva CA, Chalouni C, Williams A, Hartl D, Lee CG, Elias JA. 2009. Chitin is a size-dependent regulator of macrophage TNF and IL-10 production. J Immunol 182:3573-3582 http://dx.doi.org/10.4049/ iimmunol.0802113.

171. Hohl TM, Feldmesser M, Perlin DS, Pamer EG. 2008. Caspofungin modulates inflammatory responses to Aspergillus fumigatus through stage-specific effects on fungal beta-glucan exposure. J Infect Dis 198: 176-185 http://dx.doi.org/10.1086/589304.

172. Lamaris GA, Lewis RE, Chamilos G, May GS, Safdar A, Walsh TJ, Raad II, Kontoyiannis DP. 2008. Caspofungin-mediated beta-glucan unmasking and enhancement of human polymorphonuclear neutrophil activity against Aspergillus and non-Aspergillus hyphae. J Infect Dis 198:186-192 http://dx.doi.org/10.1086/589305.

173. Rappleye CA, Goldman WE. 2008. Fungal stealth technology. Trends Immunol 29:18-24 http://dx.doi.org/10.1016/j.it.2007.10.001.

174. Wheeler RT, Fink GR. 2006. A drug-sensitive genetic network masks fungi from the immune system. PLoS Pathog 2:e35 http://dx.doi.org /10.1371/journal.ppat.0020035.

175. Dennehy KM, Ferwerda G, Faro-Trindade I, Pyz E, Willment JA, Taylor PR, Kerrigan A, Tsoni SV, Gordon S, Meyer-Wentrup F, Adema GJ, Kullberg BJ, Schweighoffer E, Tybulewicz V, Mora-Montes HM, Gow NAR, Williams DL, Netea MG, Brown GD. 2008. Syk kinase is required for collaborative cytokine production induced through Dectin-1 and Toll-like receptors. Eur J Immunol 38:500-506 http://dx.doi.org/ 10.1002/eji.200737741.

176. Bulmer GS, Sans MD. 1967. Cryptococcus neoformans. II. Phagocytosis by human leukocytes. J Bacteriol 94:1480-1483.

177. Zaragoza O, Chrisman CJ, Castelli MV, Frases S, Cuenca-Estrella M, Rodríguez-Tudela JL, Casadevall A. 2008. Capsule enlargement in Cryptococcus neoformans confers resistance to oxidative stress suggesting a mechanism for intracellular survival. Cell Microbiol 10:2043-2057 http://dx.doi.org/10.1111/j.1462-5822.2008.01186.x.

178. Wozniak KL, Levitz SM. 2008. Cryptococcus neoformans enters the endolysosomal pathway of dendritic cells and is killed by lysosomal components. Infect Immun 76:4764-4771 http://dx.doi.org/10.1128/IAI .00660-08.

179. Alvarez M, Casadevall A. 2006. Phagosome extrusion and host-cell survival after Cryptococcus neoformans phagocytosis by macrophages. Curr Biol 16:2161-2165 http://dx.doi.org/10.1016/j.cub.2006.09.061.

180. Ma H, Croudace JE, Lammas DA, May RC. 2006. Expulsion of live pathogenic yeast by macrophages. Curr Biol 16:2156-2160 http://dx.doi .org/10.1016/i.cub.2006.09.032.

181. Dadachova E, Casadevall A. 2008. Ionizing radiation: how fungi cope, adapt, and exploit with the help of melanin. Curr Opin Microbiol 11:525-531 http://dx.doi.org/10.1016/j.mib.2008.09.013.

182. Dadachova E, Bryan RA, Huang X, Moadel T, Schweitzer AD, Aisen P, Nosanchuk JD, Casadevall A. 2007. Ionizing radiation changes the electronic properties of melanin and enhances the growth of melanized fungi. PLoS One 2:e457 http://dx.doi.org/10.1371/journal.pone.0000457. 183. Doering TL, Nosanchuk JD, Roberts WK, Casadevall A. 1999. Melanin as a potential cryptococcal defence against microbicidal proteins. Med Mycol 37:175-181 http://dx.doi.org/10.1080/j.1365-280X.1999 .00218.x.

184. Macho AP, Zipfel C. 2014. Plant PRRs and the activation of innate immune signaling. Mol Cell 54:263-272 http://dx.doi.org/10.1016 j.j.molcel.2014.03.028.

185. Couto D, Zipfel C. 2016. Regulation of pattern recognition receptor signalling in plants. Nat Rev Immunol 16:537-552 http://dx.doi.org /10.1038/nri.2016.77.

186. Sánchez-Vallet A, Mesters JR, Thomma BPHJ. 2015. The battle for chitin recognition in plant-microbe interactions. FEMS Microbiol Rev 39:171-183 http://dx.doi.org/10.1093/femsre/fuu003.

187. Mentlak TA, Kombrink A, Shinya T, Ryder LS, Otomo I, Saitoh H, Terauchi R, Nishizawa Y, Shibuya N, Thomma BP, Talbot NJ. 2012. Effector-mediated suppression of chitin-triggered immunity by Magnaporthe oryzae is necessary for rice blast disease. Plant Cell 24:322-335 http://dx.doi.org/10.1105/tpc.111.092957.

188. Oliveira-Garcia E, Deising HB. 2013. Infection structure-specific expression of $\beta-1,3$-glucan synthase is essential for pathogenicity of Colletotrichum graminicola and evasion of $\beta$-glucan-triggered immunity in maize. Plant Cell 25:2356-2378 http://dx.doi.org/10.1105/tpc.112 .103499 .

189. Casadevall A, Pirofski LA. 2006. Polysaccharide-containing conjugate vaccines for fungal diseases. Trends Mol Med 12:6-9 http://dx.doi .org/10.1016/j.molmed.2005.11.003.

190. Cassone A. 2008. Fungal vaccines: real progress from real challenges. Lancet Infect Dis 8:114-124 http://dx.doi.org/10.1016/S1473-3099(08) 70016-1.

191. Cutler JE, Deepe GS Jr, Klein BS. 2007. Advances in combating fungal diseases: vaccines on the threshold. Nat Rev Microbiol 5:13-28 http://dx.doi.org/10.1038/nrmicro1537.

192. Dan JM, Levitz SM. 2006. Prospects for development of vaccines against fungal diseases. Drug Resist Updat 9:105-110 http://dx.doi.org /10.1016/j.drup.2006.05.004.

193. Spellberg BJ, Ibrahim AS, Avanesian V, Fu Y, Myers C, Phan QT, Filler SG, Yeaman MR, Edwards JE Jr. 2006. Efficacy of the anti-Candida rAls3p-N or rAls1p-N vaccines against disseminated and mucosal candidiasis. J Infect Dis 194:256-260 http://dx.doi.org/10.1086/504691.

194. Ibrahim AS, Spellberg BJ, Avanesian V, Fu Y, Edwards JE Jr. 2006. The anti-Candida vaccine based on the recombinant $\mathrm{N}$-terminal domain of Als1p is broadly active against disseminated candidiasis. Infect Immun 74:3039-3041 http://dx.doi.org/10.1128/IAI.74.5.3039-3041.2006.

195. Xin H, Dziadek S, Bundle DR, Cutler JE. 2008. Synthetic glycopeptide vaccines combining beta-mannan and peptide epitopes induce protection against candidiasis. Proc Natl Acad Sci USA 105:13526-13531 http://dx.doi.org/10.1073/pnas.0803195105.

196. Sandini S, La Valle R, De Bernardis F, Macrì C, Cassone A. 2007. The $65 \mathrm{kDa}$ mannoprotein gene of Candida albicans encodes a putative beta-glucanase adhesin required for hyphal morphogenesis and experimental pathogenicity. Cell Microbiol 9:1223-1238 http://dx.doi.org /10.1111/j.1462-5822.2006.00862.x.

197. Ito JI, Lyons JM, Hong TB, Tamae D, Liu YK, Wilczynski SP, Kalkum M. 2006. Vaccinations with recombinant variants of Aspergillus fumigatus allergen Asp f 3 protect mice against invasive aspergillosis. Infect Immun 74:5075-5084 http://dx.doi.org/10.1128/IAI.00815-06.

198. Larsen RA, Pappas PG, Perfect J, Aberg JA, Casadevall A, Cloud GA, James R, Filler S, Dismukes WE. 2005. Phase I evaluation of the safety and pharmacokinetics of murine-derived anticryptococcal antibody $18 \mathrm{~B} 7$ in subjects with treated cryptococcal meningitis. Antimicrob Agents Chemother 49:952-958 http://dx.doi.org/10.1128/AAC.49.3.952-958 .2005 . 
199. Cassone A, Torosantucci A. 2006. Opportunistic fungi and fungal infections: the challenge of a single, general antifungal vaccine. Expert Rev Vaccines 5:859-867 http://dx.doi.org/10.1586/14760584.5.6.859.

200. Rachini A, Pietrella D, Lupo P, Torosantucci A, Chiani P, Bromuro C, Proietti C, Bistoni F, Cassone A, Vecchiarelli A. 2007. An anti- $\beta$-glucan monoclonal antibody inhibits growth and capsule formation of Cryptococcus neoformansin vitro and exerts therapeutic, anticryptococcal activity in vivo. Infect Immun 75:5085-5094 http://dx.doi.org/10.1128/IAI $.00278-07$.

201. Torosantucci A, Bromuro C, Chiani P, De Bernardis F, Berti F, Galli C, Norelli F, Bellucci C, Polonelli L, Costantino P, Rappuoli R, Cassone A. 2005. A novel glyco-conjugate vaccine against fungal pathogens. J Exp Med 202:597-606 http://dx.doi.org/10.1084/jem.20050749. 202. Hancock RE, Sahl HG. 2006. Antimicrobial and host-defense peptides as new anti-infective therapeutic strategies. Nat Biotechnol 24: 1551-1557 http://dx.doi.org/10.1038/nbt1267.

203. Li XS, Reddy MS, Baev D, Edgerton M. 2003. Candida albicans Ssa1/2p is the cell envelope binding protein for human salivary histatin 5 . J Biol Chem 278:28553-28561 http://dx.doi.org/10.1074/jbc.M300680 200.

204. Hilpert K, Elliott M, Jenssen H, Kindrachuk J, Fjell CD, Körner J, Winkler DF, Weaver LL, Henklein P, Ulrich AS, Chiang SH, Farmer SW, Pante N, Volkmer R, Hancock RE. 2009. Screening and characterization of surface-tethered cationic peptides for antimicrobial activity. Chem Biol 16:58-69 http://dx.doi.org/10.1016/j.chembiol.2008.11.006.

205. Stynen D, Goris A, Sarfati J, Latgé JP. 1995. A new sensitive sandwich enzyme-linked immunosorbent assay to detect galactofuran in patients with invasive aspergillosis. J Clin Microbiol 33:497-500.

206. Morelle W, Bernard M, Debeaupuis JP, Buitrago M, Tabouret M, Latgé J-P. 2005. Galactomannoproteins of Aspergillus fumigatus. Eukaryot Cell 4:1308-1316 http://dx.doi.org/10.1128/EC.4.7.1308-1316.2005.

207. Sendid B, Jouault T, Coudriau R, Camus D, Odds F, Tabouret M, Poulain D. 2004. Increased sensitivity of mannanemia detection tests by joint detection of $\alpha$ - and $\beta$-linked oligomannosides during experimental and human systemic candidiasis. J Clin Microbiol 42:164-171 http://dx .doi.org/10.1128/JCM.42.1.164-171.2004.
208. Babady NE, Bestrom JE, Jespersen DJ, Jones MF, Beito EM, Binnicker MJ, Wengenack NL. 2009. Evaluation of three commercial latex agglutination kits and a commercial enzyme immunoassay for the detection of cryptococcal antigen. Med Mycol 47:336-338 http://dx.doi . org/10.1080/13693780802607400.

209. McFadden DC, Zaragoza O, Casadevall A. 2004. Immunoreactivity of cryptococcal antigen is not stable under prolonged incubations in human serum. J Clin Microbiol 42:2786-2788 http://dx.doi.org/10.1128 /JCM.42.6.2786-2788.2004.

210. Marty FM, Koo S. 2009. Role of $(1 \rightarrow 3)-\beta$-D-glucan in the diagnosis of invasive aspergillosis. Med Mycol 47(Suppl 1):S233-S240 http://dx.doi .org/10.1080/13693780802308454.

211. Ostrosky-Zeichner L, Alexander BD, Kett DH, Vazquez J, Pappas PG, Saeki F, Ketchum PA, Wingard J, Schiff R, Tamura H, Finkelman MA, Rex JH. 2005. Multicenter clinical evaluation of the $(1 \rightarrow 3) \beta$-Dglucan assay as an aid to diagnosis of fungal infections in humans. Clin Infect Dis 41:654-659 http://dx.doi.org/10.1086/432470.

212. Duro RM, Netski D, Thorkildson P, Kozel TR. 2003. Contribution of epitope specificity to the binding of monoclonal antibodies to the capsule of Cryptococcus neoformans and the soluble form of its major polysaccharide, glucuronoxylomannan. Clin Diagn Lab Immunol 10: 252-258.

213. Cheetham J, Smith DA, da Silva Dantas A, Doris KS, Patterson MJ, Bruce CR, Quinn J. 2007. A single MAPKKK regulates the Hog1 MAPK pathway in the pathogenic fungus Candida albicans. Mol Biol Cell 18: 4603-4614 http://dx.doi.org/10.1091/mbc.E07-06-0581.

214. Román E, Arana DM, Nombela C, Alonso-Monge R, Pla J. 2007. MAP kinase pathways as regulators of fungal virulence. Trends Microbiol 15:181-190 http://dx.doi.org/10.1016/j.tim.2007.02.001.

215. Kozubowski L, Lee SC, Heitman J. 2009. Signalling pathways in the pathogenesis of Cryptococcus. Cell Microbiol 11:370-380 http://dx.doi .org/10.1111/j.1462-5822.2008.01273.x.

216. Steinbach WJ, Reedy JL, Cramer RA Jr, Perfect JR, Heitman J. 2007. Harnessing calcineurin as a novel anti-infective agent against invasive fungal infections. Nat Rev Microbiol 5:418-430 http://dx.doi.org $\underline{\text { /10.1038/nrmicro1680. }}$. 